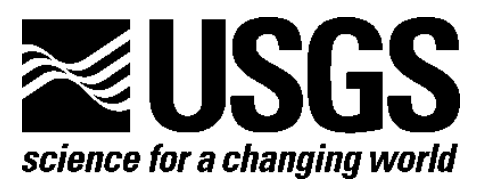

\title{
Biological Assessment of Environmental Flows for Oklahoma
}

By William L. Fisher, Titus S. Seilheimer, and Jason M. Taylor

Open-File Report 2012-1114

U.S. Department of the Interior

U.S. Geological Survey 


\section{U.S. Department of the Interior \\ KEN SALAZAR, Secretary}

\section{U.S. Geological Survey \\ Marcia K. McNutt, Director}

U.S. Geological Survey, Reston, Virginia: 2012

For more information on the USGS-the Federal source for science about the Earth, its natural and living resources, natural hazards, and the environment-visit http://www.usgs.gov or call 1-888-ASK-USGS

For an overview of USGS information products, including maps, imagery, and publications, visit $h$ ttp://www.usgs.gov/pubprod

To order this and other USGS information products, visit $h$ ttp://store.usgs.gov

Suggested citation:

Fisher, W.L., Seilheimer, T.S., and Taylor, J.M., 2012, Biological assessment of environmental flows for Oklahoma: U.S. Geological Survey Open-File Report 2012-1114, 43 p., available at http://pubs.usgs.gov/of/2012/1114/.

Any use of trade, product, or firm names is for descriptive purposes only and does not imply endorsement by the U.S. Government.

Although this report is in the public domain, permission must be secured from the individual copyright owners to reproduce any copyrighted material contained within this report. 


\section{Acknowledgements}

We thank Ellen Tejan of Enogex, LCC for providing us with complied fish records for the State of Oklahoma. Additional fish data were provided by Gust Annis, Dorothy Butler, and Michael Morey of the Missouri Resource Assessment Partnership, Mark Van Scoyoc of the Kansas Department of Wildlife and Parks, Daniel Millican of The Nature Conservancy of Arkansas, and Brooks Tramell of the Oklahoma Conservation Commission. 


\section{Contents}

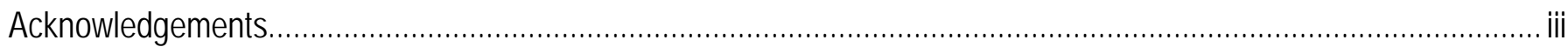

Abstract ……

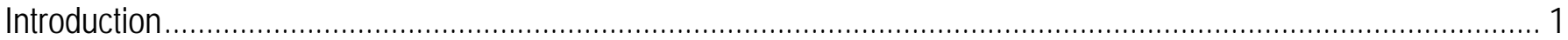

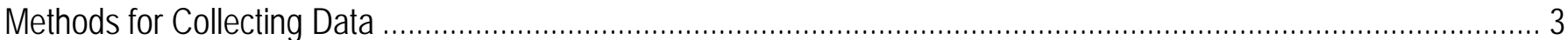

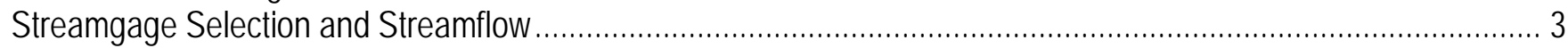

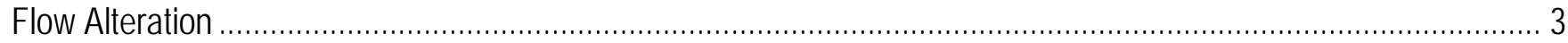

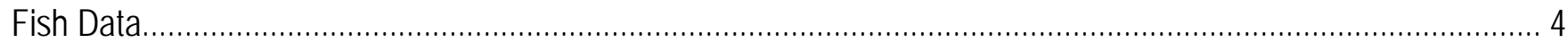

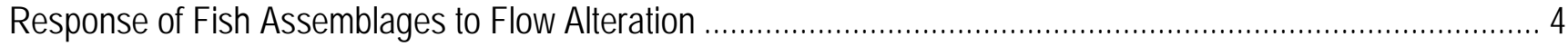

Temporal Response of Fish Assemblage Structure to Flow Alteration........................................................... 5

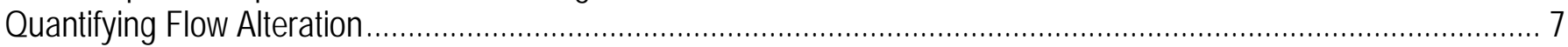

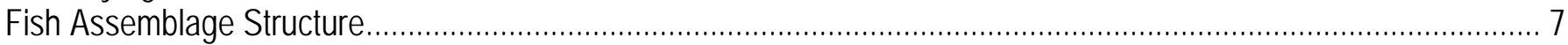

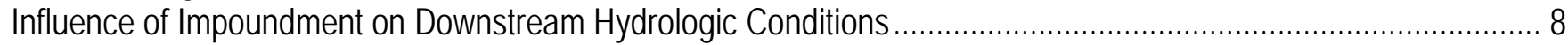

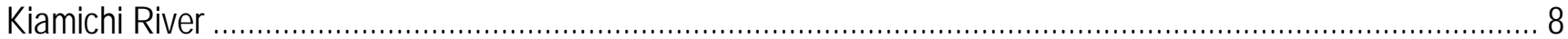

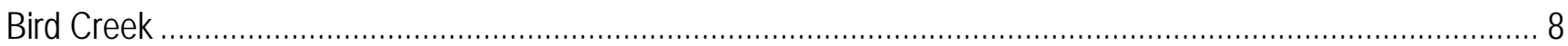

Influence of Impoundment on Downstream Fish Assemblage Structure ........................................................ 9

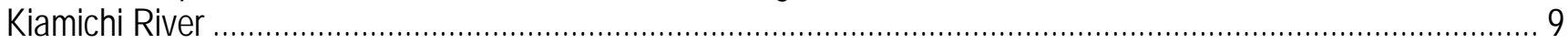

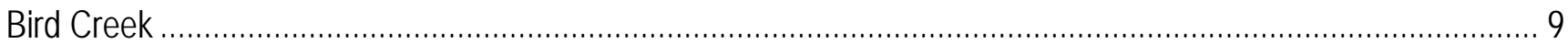

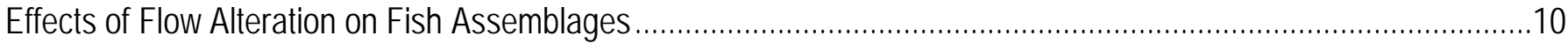

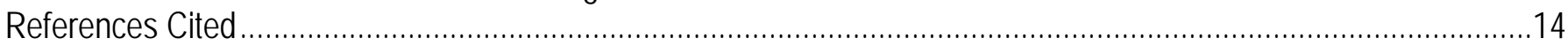

Appendix 1.-Family, Scientific Name, Common Name, and Functional Group Membership for Species

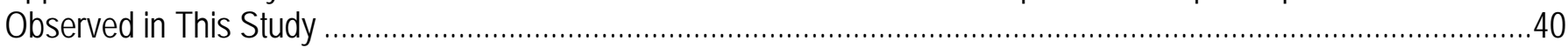

\section{Figures}

1. Map showing streamgage location and contributing watersheds for reference and altered sites

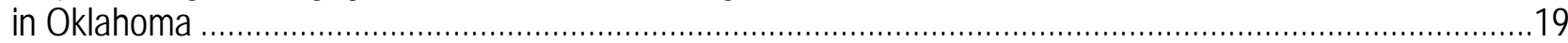

2. $\quad$ Map of the watershed on A, Bird Creek and B, Kiamichi River, Oklahoma................................................21

3. Ordination biplot from nonmetric multidimensional scaling (NMS; Jaccard) of species presence for fishes associated with 28 streamgages on reference and altered streams in Oklahoma.......................................22

4. Ordination biplot from principal components (PC) analysis of proportion of functional groups for 28 streamgages on reference and altered streams in Oklahoma ....

5. Charts showing nonmetric multidimensional scaling (NMS) ordination based on fish species composition for sampling events conducted during the early summer over 18 years at one location on $A$, the Kiamichi River and B, Bird Creek, Oklahoma.

6. Chart showing annual variation in three hydrologic parameters that were significantly correlated with differences in fish assemblage structure in the Kiamichi River near Antlers, Oklahoma.....

7. Charts showing annual variation in five hydrologic parameters that were significantly correlated with differences in fish assemblage structure in Bird Creek near Sperry, Oklahoma. 


\section{Tables}

1. Names of 27 flow indices used in this study grouped by magnitude, frequency and duration .......................27

2. Study streamgages with U.S. Geological Survey codes, HIP classification group, alteration status,

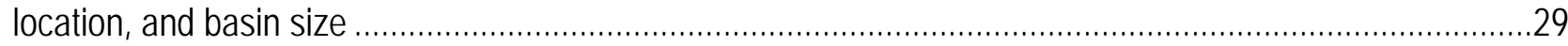

3. 5th and 95th percentiles for 27 hydrologic indices for the four HIP groups .............................................30

4. Observed and predicted HIP grouping with disciminant analysis for 28 Oklahoma streamgages...................32

5. Correlations between first and second NMS axes of species presence and functional groups with flow variables .......................................................................................................................

6. Mean proportion of species in functional groups for alteration (reference or altered hydrology), and geographic location (eastern or western) of streamgages

7. Differences between periods in median and coefficient of dispersion values for Kiamichi River hydrologic

parameters

8. Differences between periods in median and coefficient of dispersion values for Bird Creek hydrologic

parameters

9. Correlation coefficients and $p$-values for best fit environmental vectors describing relationships between environmental flow variables and fish assemblage structure in the Kiamichi River and Bird Creek,

Oklahoma

10. Fish species that were significant indicators of pre- or post-impoundment periods on the Kiamichi River and Bird Creek, Oklahoma

\section{Conversion Factors}

Inch/Pound to SI

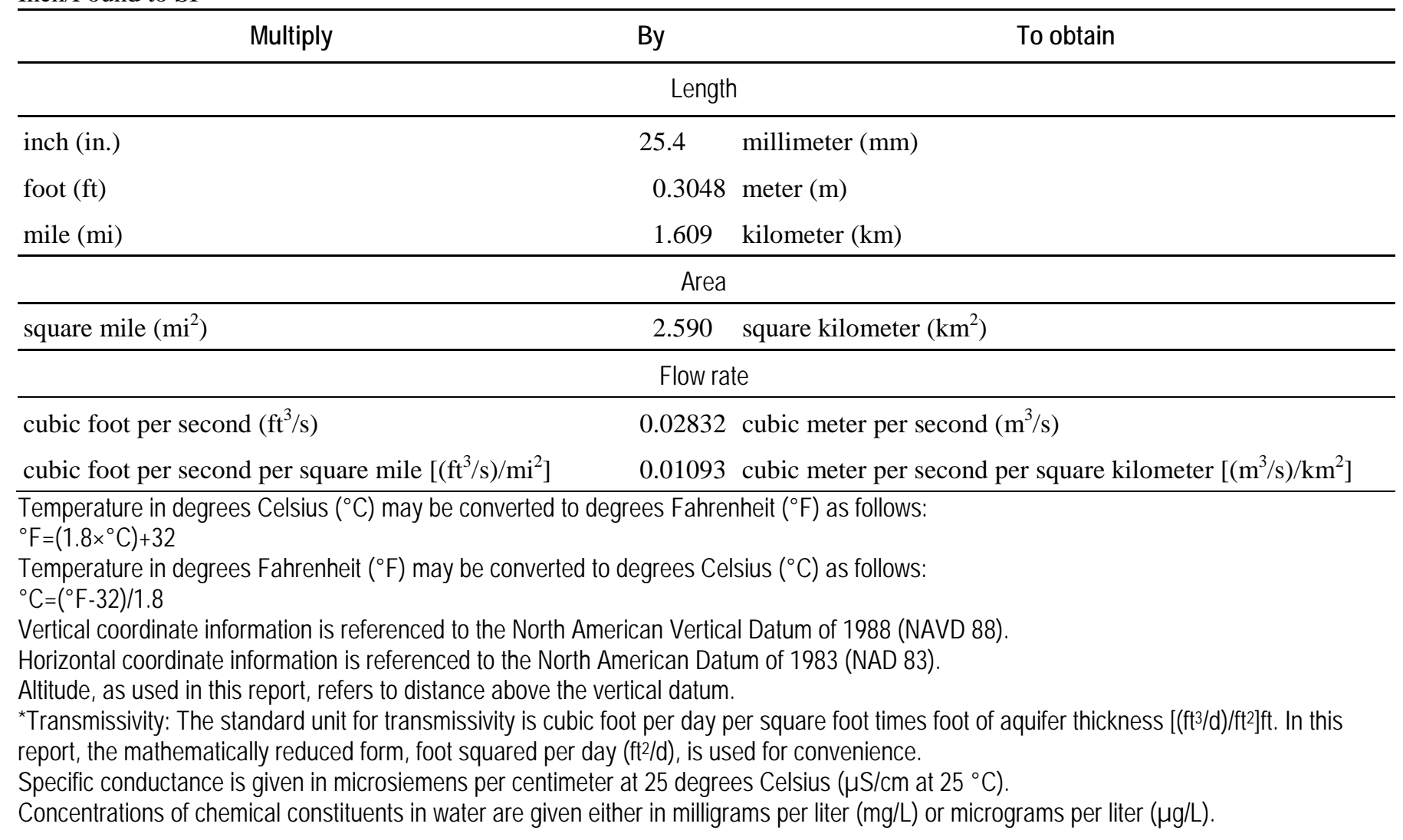




\section{Abbreviations}

BCD Bray-Curtis dissimilarity

HIP hydroecological integrity assessment process

HIT hydrologic index tool

IHA indicators of hydrologic alteration

NMS nonmetric multidimensional scaling

RVA range of variability

USGS U.S. Geological Survey 


\title{
Biological Assessment of Environmental Flows for Oklahoma
}

\author{
By William L. Fisher, ${ }^{1}$ Titus S. Seilheimer, ${ }^{2}$ and Jason M. Taylor ${ }^{2}$
}

\begin{abstract}
Large-scale patterns in fish assemblage structure and functional groups are influenced by alterations in streamflow regime. In this study, we defined an objective threshold for alteration for Oklahoma streams using a combination of the expected range of 27 flow indices and a discriminant analysis to predict flow regime group. We found that fish functional groups in reference flow conditions had species that were more intolerant to flow alterations and preferences for stream habitat and faster flowing water. In contrast, altered sites had more tolerant species that preferred lentic habitat and slower water velocity. Ordination graphs of the presence and functional groups of species revealed an underlying geographical pattern roughly conforming to ecoregions, although there was separation between reference and altered sites within the larger geographical framework.

Additionally, we found that reservoir construction and operation significantly altered fish assemblages in two different systems, Bird Creek in central Oklahoma and the Kiamichi River in southeastern Oklahoma. The Bird Creek flow regime shifted from a historically intermittent stream to one with stable perennial flows, and changes in fish assemblage structure covaried with changes in all five components of the flow regime. In contrast, the Kiamichi River flow regime did not change significantly for most flow components despite shifts in fish assemblage structure; however, most of the species associated with shifts in assemblage structure in the Kiamichi River system were characteristic of lentic environments and were likely related more to proximity of reservoirs in the drainage system than changes in flow. The spatial patterns in fish assemblage response to flow alteration, combined with different temporal responses of hydrology and fish assemblage structure at sites downstream of reservoirs, indicate that interactions between flow regime and aquatic biota vary depending on ecological setting. This supports the notion that regional variation in natural flow regimes could affect the development of flow recommendations.
\end{abstract}

\section{Introduction}

Oklahoma has a wide range of climatic and environmental conditions that create variation in stream hydrology and water availability across the State. Climate ranges from humid subtropical in the east to semiarid in the west, and these climatic differences influence environmental conditions and the flow regime of streams and rivers throughout the State (Turton

\footnotetext{
${ }^{1}$ U.S. Geological Survey.

${ }^{2}$ Cornell University.
} 
and others, 2009). Environmental flows are defined as the quantity, timing, and quality of water flows required to sustain freshwater and estuarine ecosystems and the human livelihood and well-being that depend on these ecosystems (Poff and others, 2010). A better understanding of environmental flows and how flow regimes influence aquatic ecosystems in Oklahoma can help assess the impacts of flow-related changes on aquatic organisms, such as fish assemblages. Such an assessment could inform water management in Oklahoma under current and future conditions.

The hydrologic flow regime has a direct influence on the structure and function of aquatic ecosystems and is the primary driver of ecological integrity of a river ecosystem. Alteration of the hydrologic regime of rivers from impoundments and flow diversions modifies the structure and function of river ecosystems (Poff and others, 1997; Rosenberg and others, 2000; Postel and Richter, 2003; Poff and others, 2007). Hydrologic alterations_-such as flow stabilization, prolonged low flows, loss of seasonal flow peaks, rapid changes in river stage, and low or high water temperatures downstream-disrupt life cycles of aquatic plants, invertebrates, and fishes, resulting in a reduction in species diversity and modifying reproduction and growth rates that oftentimes lead to local extinctions of native species and the invasion and establishment of exotic species (Poff and others, 1997). Large water diversions deplete streamflows, sometimes to damaging levels, affecting aquatic and floodplain habitats, aquatic biodiversity, sport and commercial fisheries, natural floodplain fertility, and natural flood control (Postel and Richter, 2003). The development of water resources to meet the demands of urban population centers is growing and threatens the ecological integrity of many freshwater ecosystems (Fitzhugh and Richter, 2004).

Alterations in the flow regime of streams can be reflected in the composition of the aquatic biota (Poff and Zimmerman, 2010), which makes flow regime a useful indicator of ecological integrity. Procedures and tools for measuring flow regime and alteration of flow are available through the software Indicators of Hydrologic Alteration (IHA; Richter and others, 1996; Matthews and Richter, 2007) and Hydroecological Integrity Assessment Process (HIP; Olden and Poff, 2003; Henriksen and others, 2006). A classification of unaltered streams using the HIP approach was used for Oklahoma streams and indicated that there were four general types of flow regime, describing a wide range of flow conditions: perennial runoff, perennial flashy, stable groundwater, and intermittent (Turton and others, 2009). These baseline conditions provide a reference to determine the level of alteration that has occurred in recent times and to relate to changes in biotic communities.

Individual fish species and fish assemblages respond differently to changes in flow regime. Poff and Allan (1995) found that the functional organization of fish assemblages was influenced by the degree of flow stability in a stream, whereas more variable flow regimes resulted in shifts to more generalist strategies (for example, habitat use, feeding) by the fish. Hypotheses of how ecological communities respond to hydrologic alteration provide a useful framework for assessing changes in fish assemblages to alterations in flow. In a review of the impacts of altered flow on aquatic biodiversity, fish abundance and diversity were negatively influenced by both elevated and decreased flow magnitude (Poff and Zimmerman 2010). The authors called for better-defined thresholds for flow alteration-ecological response relationships. This study addresses this need for rivers in Oklahoma.

Improving our understanding of the response of aquatic organisms to flow alterations is an important step in the development of water resource management that incorporates protection of Oklahoma's aquatic resources. Our objectives were to (1) quantify the thresholds of alteration for important flow indices, (2) test the configuration of functional fish groups in relation to flow 
alteration, and (3) identify patterns in fish assemblages associated with flow regime in all sites. Finally, we provide a detailed example of the impacts of impoundments on downstream flow regimes and resulting changes in fish assemblages at two sites in Oklahoma, the Kiamichi River and Bird Creek.

\section{Methods for Collecting Data}

\section{Streamgage Selection and Streamflow}

We chose 168 streams with gages draining areas smaller than 2,500 square miles in or adjacent to Oklahoma (Esralew, 2010) for our original analysis of reference streams. From this larger set of gaged streams, we chose a subset of 88 streams with a known reference flow regime and that were previously classified into streamflow groups (Turton and others, 2009). These streams and their previous classifications provided a benchmark to determine if their flow regime had been altered. To minimize the effect of climatic variation on localized streamflow, we selected streamgages that monitored flow for a concurrent period. A 15-year minimum period of flow data and at least 50 percent concurrent period is recommended to correctly characterize flows (Kennard and others, 2010). We selected a 20 concurrent year period (1988-2007), which reduced the number of potential streamgages from 88 to 41. Streamgage information (daily mean and peak flows) was obtained from the U.S. Geological Survey (USGS) National Water Information System (http://waterdata.usgs.gov/nwis/) for full water years (October-August) from 1988 through 2007. This recent period was selected because it was more likely to coincide with available fish data. We used the Hydrologic Index Tool (HIT, version 1.48; U.S. Geological Survey, undated) to calculate 171 flow indices for each study stream (Turton and others, 2009). These flow indices describe the entire flow regime, including magnitude of average, low, and high flows, frequency of low and high flow, duration of low and high flow, timing of flow events, and rate of change (Olden and Poff, 2003).

\section{Flow Alteration}

We used two statistical techniques to quantify alteration in Oklahoma streams. In the first, we fit distributions and identified the 5th and 95th percentiles (Arthington, 2006) for the reference flow period of the four flow groups reported by Turton and others (2009) for 88 gaged streams. The group notation adopted by Turton and others (2009) was retained (41, 42, 43, and 44), which corresponded to general flow regime descriptions of perennial runoff (41), perennial flashy (41), stable groundwater (43), and intermittent (44). The 27 flow indices we used (table 1) were identified as the best combination of variables from the available 171 flow indices to categorize the regions flow types. Six types of distribution-normal, lognormal, exponential, Weibull 2 parameter, Weibull 3 parameter, and Johnson Su—were fit in JMP (version 7; SAS Institute Inc., undated). The best distribution for each flow group was determined by a combination of $p$-value and visual inspection of the fit curve. The distributions were least reliable for group 43, which had only 6 member streams but had a distinctive flow regime compared with the other groups, so the distributions for group 43 were retained.

The second method used to quantify alteration was discriminant analysis. Discriminant analysis is a technique that assigns variables to pre-existing classes or groups using multiple explanatory variables (for example, flow indices; Gotelli and Ellison, 2004). We developed an algorithm to predict group classification using the same 27 flow indices as in the first method 
(table 1). The algorithm was then used to assign the streams of interest in this study to one of four flow groups. We noted when a stream changed membership in recent period because it indicated a large change in flow regime. It was also possible that a stream could not be classified into one of the four groups, which would indicate that the flow regime has been altered and does not reflect the four Oklahoma flow regimes identified by Turton and others, (2009). The current streams were assigned to reference or altered classes based on these two techniques.

\section{Fish Data}

The primary source of fish species data was from a database of Oklahoma fishes (E. Tejan, Enogex, LCC, written commun. , 2009), which contained records from the Oklahoma Conservation Commission, the Oklahoma Department of Environmental Quality, the U.S. Forest Service, and published records. Additional fish data were provided by the Kansas Department of Wildlife and Parks, the Missouri Resource Assessment Partnership, and The Nature Conservancy of Arkansas. A 15-kilometer (km) buffer (that is, radius; Poff and Allan, 1995) from each streamgage location was used to select nearest fish sampling locations in close proximity to USGS streamgages using ArcGIS (version 8.3; Environmental Research Systems Institute, Inc., undated). Only sites on the main stem of the gaged river were selected (Poff and Allan, 1995). There were 28 streamgage locations with sufficient fish data within the 15-km buffer (table 2; fig. 1). The selected streams fall within two major river basins, the Arkansas River to the north and the Red River to the south. The streams can also be divided between the wetter eastern portion of Oklahoma and drier western portion by running a vertical line to the east of streamgage 10 and west of streamgage 18 (fig. 1). A total of 150 species were found in the waters near the 28 streamgage sites (appendix 1).

\section{Response of Fish Assemblages to Flow Alteration}

Fish data were collected by different sources and with different methods, therefore we limited analysis to fish presence and the proportion of fish functional groups at each site. The coarse-scale nature of the data allowed us to identify large-scale patterns that affect Oklahoma at a regional level (Poff and Allan, 1995). Functional groupings reflect preferences for a narrow range of habitat conditions or tolerance to alteration in their environment. Fish species were assigned to groups in five functional categories: habitat type (creek, river, creek/river, lentic, general), flow velocity, trophic guild, reproductive guild, and tolerance (tolerance to water quality degradation, tolerance to habitat degradation, sensitive benthic species, conservation status). Species were assigned to functional groups based on published classes, primarily developed specifically for Oklahoma species (Jester and others, 1992), but also included additional sources for current speed (Frimpong and Angermier, 2009) and conservation status (NatureServe, 2009). Functional groups that require additional explanation are lithophilic species, reproductive guilds, and those based on Oklahoma State conservation status. Lithophilic species are species that spawn on gravel or cobble. Reproductive guilds were based on Goldstein and Simon's (1998) classification and were as follows: A_1, nonguarders, open substratum spawners; A_2, nonguarders, brood hiders; B_1, guarders, substratum choosers; B_2, guarders, nest spawners; and C_2, internal live bearers. Conservation status of species in Oklahoma is as follows: S1, critically imperiled; S2, imperiled; S3, vulnerable; S4, apparently secure; S5, secure; exotic (NatureServe, 2009). Species in multiple categories were assigned to the dominant classification (Goldstein and Simon, 1999). 
We analyzed patterns in fish assemblage structure among sites representing a range of flow alteration using ordination analysis followed by comparison of functional groups among alteration classes. Differences in assemblage structure among stream sites were quantified using nonmetric multidimensional scaling (NMS) ordinations (Minchin, 1987; Clarke, 1993) on the presence or absence of fish species with Jaccard's similarity as the distance measure. Jaccard's similarity compares homogeneity in groups, with greater distance between points indicating less similarity (McCune and Grace, 2002). Principal components analysis of the correlations was used to identify patterns in the proportions of functional groups among stream sites using the broken stick method (that is actual eigenvalues higher than eigenvalues from random variation) to identify significant components (McCune and Grace, 2002). Rank correlations between flow variables and ordination axes were calculated to determine relationships between fish assemblage structure and flow components. Differences in proportions of functional groups between altered and reference sites were tested with analysis of variance (ANOVA) in JMP. Multivariate analysis of species presence and functional groups were done in PC-ORD (version 4; Peck, 2010).

\section{Temporal Response of Fish Assemblage Structure to Flow Alteration}

We analyzed trends in hydrologic parameters associated with different periods related to reservoir construction within the Kiamichi River and Bird Creek watersheds in Oklahoma (fig. 2). Daily discharge records were obtained from USGS streamgages located downstream of reservoirs on each stream. Discharge in the Kiamichi River is influenced by Jackfork Creek, a tributary that was impounded in 1982 to form Sardis Lake. Changes in Kiamichi River flows were assessed using the combined records of USGS streamgages 07336200 and 07336500 , both located near Antlers, Okla., downstream of Sardis Lake and upstream of Hugo Lake. Daily flow records from two gages were used to incorporate a period of record long enough to estimate predam conditions (more than 20 years) (Kennard and others, 2010). The combined record spanned 81 years (1926-2007) and included daily flow data that corresponded with available fish data (1977-1996). To assess changes in hydrology within Bird Creek, we used USGS streamgage 07177500 located downstream of Birch and Skiatook Lakes near Sperry, Okla. The gage record spanned 49 years (1938-2007) and included daily flow data that corresponded with fish data (1978-1996) collected on Bird Creek. Discharge in Bird Creek is influenced by a tributary that was impounded in 1977 to form Birch Lake and a second reservoir on the main stem, Skiatook Lake, which was impounded in 1984.

We used a dataset consisting of fish collections from about 40 different sampling events at the same location on each stream to assess temporal changes in fish assemblage structure between 1977 and 1996. Fish sampling was conducted by the Oklahoma Department of Environmental Quality using a standardized sampling effort of twenty 10-meter (m) seine hauls made with a 3-m × 1.5-m (4.7-millimeter mesh) lead weighted seine. Sampling effort was approximately 1 hour per sampling event. We limited data for analysis to collections that were made in early summer (June and July) because this period was sampled every year, whereas late summer and early fall sampling effort varied among years. When multiple early summer sampling events occurred within one year, we kept both events to include potential effects of within-year variation in the analysis. We excluded data for the year preceding and the year of impoundment to remove any potential effects of dam construction not related to flow alteration from the dataset. This resulted in a total of 26 (Kiamichi River) and 23 (Bird Creek) sampling events, representing 17 different summers that we retained for analysis. 
We used the IHA software (version 7.1; ConserveOnline, undated) to assess potential differences in hydrologic conditions between pre- and post-impoundment periods for each stream. The pre-impoundment period was between 1926 and 1980 for the Kiamichi River, after which flows were potentially altered by Sardis Lake reservoir operations (1983-2007). Bird Creek had three periods, including the pre-impoundment (1958-1976), post-Birch Lake impoundment (1978-1982), and post-Skiatook Lake impoundment (1985-2007) periods.

The IHA method is based on 33 biologically relevant hydrologic parameters divided among five fundamental characteristics of hydrologic regimes that represent temporal changes in water conditions (for example, water levels, discharge rates; Richter and others, 1996). These characteristics include the magnitude, timing of occurrence, frequency of occurrence, duration of time, and the rate of change in specific water conditions. We used the nonparametric statistics option to compare median and coefficient of variation values between pre- and postimpoundment periods using a permutation procedure (1,000 permutations) to identify significant differences between periods. We also used the range of variability (RVA) approach to assess changes in IHA parameters between periods (Richter and others, 1997). The RVA approach divides the data from the period before the event for each parameter into three different categories based on the 17th percentiles from the median yielding three categories of equal size. We used RVA to compare medians between pre- and post-impoundment periods in relation to RVA boundaries calculated for the pre-impoundment period.

Patterns in fish assemblage structure between sampling events were quantified using NMS ordinations (Minchin, 1987; Clarke, 1993) on $\log _{10}(\mathrm{x})$-transformed abundances of fish species with Bray-Curtis dissimilarity (BCD) as the distance measure. Prior to analysis, fish species occurring in less than two sampling events ( $<5$ percent) were excluded from the dataset to reduce noise (McCune and Grace, 2002). We used rotational vector fitting to relate hydrologic parameters from IHA to gradients in fish assemblage structure quantified by the NMS ordination (Faith and Norris, 1989). Vector fitting finds the direction of the maximum correlation for each environmental variable and assesses significance of the fitted environmental vectors using a permutation procedure (1,000 permutations) (Oksanen and others, 2010). Some hydrologic variables were $\log _{10}(\mathrm{x})$-transformed to improve assumptions of normality (McCune and Grace, 2002). Ordination plots were rotated to have the strongest correlation with environmental flow vectors on the horizontal x-axis(axis 1) of the plots. We also examined the response of downstream fish assemblages to impoundment by comparing centroids and dispersion of sampling events within pre- and post-impoundment groups within ordination space using permutational multivariate analysis of variance (PERMANOVA) and permutational analysis of multivariate dispersion (PERMDISP; Anderson 2001, 2006). We assigned sampling events to pre-impoundment and post-impoundment periods for both the Kiamichi River and Bird Creek. An addition sampling period, transitional, was added between the pre-impoundment and postimpoundment periods to assess differences in fish assemblage structure among these three periods.

We used Indicator Species Analysis (ISA; Dufrêne and Legendre, 1997) to test for affinities of different species to our period grouping. ISA measures association between species and predetermined groups by calculating an indicator value (IndVal) based on species abundances weighted by their occurrence within each group. We estimated the probability of achieving an equal or larger IndVal value among groups $(p)$ using a bootstrap method based on 999 random permutations of the original data. All ordination analysis was conducted in $\mathrm{R}$ statistical language, version 2.11.2 (R Core Development Team, 2010) using the vegan package 
for NMS, PERMANOVA, and PERMDISP (R Core Development Team, 2010; Oksanen and others, 2011). Indicator species analysis was performed using PC-ORD (version 5.0; McCune and Grace, 2002).

\section{Quantifying Flow Alteration}

The 20-year period of flow data for 14 streams corresponded to the reference period used in the earlier classification; these data are referred to as "reference" in table 2 (Turton and others, 2009). Streams were considered to have an altered flow regime when upstream anthropogenic regulation of flows, such as impoundments or water withdrawal, were present and when the period of the streamflow record we analyzed was not in the least-altered period (Esralew, 2010). The expected range (5th and 95th percentile; table 3) of flow indices differed greatly between flow regime groups. We compared index values for streams with the expected range and counted the number exceeding the expected range of threshold and average percent exceeded (table 4). The reference streams had lower numbers and percentages of flow indices exceeding the expected values. The mean percent exceeding was higher in the altered streams than the reference streams.

The discriminant analysis using 27 flow metrics correctly classified 86 of the 88 streams into the four flow groups. The discriminant analysis algorithm was then used to predict flow regime groups for the 28 study streams. The reference streams were all classified correctly, while only 5 of 14 altered streams were the same group as before discriminant analysis (table 4). Three streams shifted from group 42 to 43 , while one stream in group 42 did not classify into any of the defined four groups. Five streams in group 44 changed to 41, 42, and 43. The least common flow regime group in Turton and others (2009) was 43 (stable groundwater; six streams), but it was the most common group that altered streams fell under because of elevated flows, which indicates there was an increase in flow and stability.

\section{Fish Assemblage Structure}

Nonmetric multidimensional scaling (NMS) ordination of 28 fish sampling sites identified two axes (2D) that explained 85.8 percent of the variation in original distances among fish sampling sites $(2 \mathrm{D}$ stress $=13.5$ ). NMS axis 1 (x axis) represented changes in species composition along a gradient of decreasing variability in daily flows (MA04), variability in May flows (MA28), frequency of low flow spells (FL03), high flood pulse count (FH04), variability in annual maximums of 90-day means of daily discharge (DH10), constancy (TA01), and fall rate (RA03). NMS axis 2 (y axis) represented changes in species composition related to increasing variability in annual maximums of 3-day means of daily discharge (DH07), DH10, and RA03 (table 5). These changes in flow environments appeared to represent geographic variation in flow more than flow alteration, as sites were primarily ordinated based on location rather than alteration, although eastern Oklahoma sites show some difference between altered and reference samples (fig. 3). Streams grouped by basin were clearly separated from each other, particularly the eastern basins from the western streams. Altered sites within the two eastern basins tended to shift away from reference sites along a trajectory correlated with increasing MA04, MA28, FL03, FH04, and TA01 (fig. 3; table 5). In contrast, there was considerable overlap between reference and streams with altered hydrology among western streams (fig. 3). In general, westerns stream represented fish assemblages associated with higher DH10 and RA03 (fig. 3; table 5). 
Principal components analysis of fish functional group proportions at sites identified two significant principal components (fig. 4). These two axes explained 63.2 percent of the variation in the data. There were nine indices positively correlated with PC1 (MA04, MA28, specific mean annual maximum flows (MH20), FL03, flood frequency (FH05), number of zero-flow days (DL18), DH10, TA01, RA03, and five indices negatively correlated with PC2 [mean daily flow (MA01), mean minimum January flow (ML01), mean maximum April flow (MH04), and no daily rises (RA05)] (table 5). There were similar relationships in the PCA plot compared with those in the NMS plot (fig. 3). There was reasonable separation among eastern Red River, Arkansas River, western stream sites, and there was some separation of reference streams verses those with altered hydrology along a trajectory associated with small streams on the steams loading the highest (that is more distinct functional group configuration) on the second principle component compared to larger reference streams with negative values on the second axis in eastern streams (fig. 4). There was no evidence of differing functional structure within fish assemblages between reference and altered streams among the western basins (fig. 4).

We compared the proportion of functional groups between altered and reference sites assigned with discriminant analysis (table 6). There were higher proportions of species in reference locations that were intolerant to water quality and habitat degradation, more sensitive benthic species and lithophilic spawners, and species associated with fast flowing water. Altered sites had more tolerant species that preferred lentic conditions and slower flowing waters. Generalist broadcast spawners (A_1) were more common in altered locations, while brood hiders were more common in reference sites (A_2). We identified a geographical trend of more intolerant species in streams with fast flowing water and imperiled species in the eastern portion of the State compared with the more generalist groups in the western portion (table 6).

\section{Influence of Impoundment on Downstream Hydrologic Conditions}

\section{Kiamichi River}

The impoundment of Jackfork Creek by Sardis Lake dam had limited effects on downstream hydrology of the Kiamichi River. Median December flows and variation in January flows were significantly higher after impoundment (table 7). There were no differences in magnitude and duration of minimum flows between the periods, but median 3- and 7-day maximum flows significantly decreased between the two periods (table 7). We did not observe any significant differences in the timing of annual extreme events between the pre- and postimpoundment periods. High flow pulses and flow reversals were more frequent after impoundment (table 7).

\section{Bird Creek}

Flow alteration due to the impoundment of Birch Creek, a tributary of Bird Creek, had minimal effects on the overall hydrologic conditions in Bird Creek. Only three parameters, median monthly flows for May and June and the number of flow reversals in Bird Creek, were significantly higher after the construction of Birch Lake (table 8). In contrast, several hydrologic parameters, representing all five components of the flow regime, were significantly altered by the impoundment of Bird Creek and construction of Skiatook Lake. Reservoir release patterns resulted in significantly higher median monthly flows for all 12 months with the months of May and June exhibiting more variation in median flow. The magnitude and duration of annual extreme conditions, particularly low flows, was significantly altered. Median annual minimum 
flows increased dramatically and the base flow index increased by an order of magnitude between the pre-impoundment and post-Skiatook-impoundment periods. Additionally, the median annual 30-day maximum flow was higher post impoundment. There were no significant reservoir effects on the timing of minimum flows, but the annual 1-day maximum flow occurred later in the year after the impoundment of Skiatook Lake. Low flow pulses never occurred and duration of high flow pulses increased significantly from 4 to 6 days after impoundment of Bird Creek by Skiatook Lake. The rate and frequency of changes in discharge were significantly altered by reservoir operations with faster fall rates and more frequent and variable flow reversals per year (table 8).

\section{Influence of Impoundment on Downstream Fish Assemblage Structure}

\section{Kiamichi River}

Twenty-six sampling events ordinated in fish species multidimensional space identified three axes (3D) that explained 76.5 percent of the variation in original distances among sampling events (3D stress $=15.8$ ). Despite only explaining 17 percent of the variation, NMS axis 1 ( $\mathrm{x}$ axis) had strong associations with median flows for September, magnitude and duration of low flows (7-day minimum), frequency of flow reversals, and daily discharge for the sampling date (fig. 5A, table 9). Frequency of flow reversals was the only hydrologic parameter related to fish community structure that was altered after the impoundment of Sardis Lake (fig. 6C, table 7). However, there were positive trends in September median flows, 7-day minimum flows, and number of flow reversals across the period of record associated with available fish data (fig. 6B, $\mathrm{D}$, and F). Additionally, there were significant differences in fish species composition $(F)$ between pre- and post-impoundment periods using both the two-group (PERMANOVA $F_{1,24}=$ 5.52, $p<0.002$ ) and three-group (PERMANOVA $F_{1,24}=6.96, p<0.001$ ) structure. There were no differences in multivariate dispersion among the pre- and post-dam construction periods (PERMDISP $F_{1,24}=0.07, p=0.792$ ) or among the pre-dam, transitional, or post-dam construction periods (PERMDISP $F_{2,23}=0.09, p=0.911$ ). Brook silversides (Labidesthes sicculus) was a significant indicator species for pre-impoundment conditions, whereas increased abundance of blacktail shiners (Cyprinella venusta) was positively associated with the postimpoundment period (table 10). Among bass species, spotted bass (Micropterus punctulatus) were more abundant and frequent in pre-impoundment collections while largemouth bass (Micropterus salmoides) were significant indicators of post-impoundment conditions, particularly during the transitional period (table 10).

\section{Bird Creek}

Nonmetric multidimensional scaling (NMS) ordination of 23 sampling events in fish species space identified three axes that explained 83.3 percent of the variation in original distances among fish sampling events (3D stress $=13.07$ ). More than half of the explained variation (46.6 percent) was attributed to NMS axis 1 (x axis), which had strong associations with increased median flows during typical low flow months (July, August, September, and October), December flows, minimum flows (1st, 3d, 7th, 30th, and 90th day), and number of flow reversals, as well as decreased number and duration of low flow events (fig. 5B, table 9). All these hydrologic parameters responded dramatically to flow alteration associated with water management practices at Skiatook Lake (fig. 7, table 8). Pre- and post-impoundment periods were clearly separated on NMS axis 1 (fig. 5B), and some separation between the transitional 
and post-impoundment periods occurred on NMS axis 2 (y axis; fig. 5B). Pre- and postimpoundment fish assemblages differed significantly in their species composition using both the two group (PERMANOVA $F_{1,21}=10.12, p<0.001$ ) and three group (PERMANOVA $F_{1,22}=$ $9.21, p<0.001)$ structure. There was a marginal difference in multivariate dispersion among the pre- and post-dam construction periods (PERMDISP $F_{1,21}=3.24, p=0.094$ ) but no difference among pre-dam, transitional, or post-dam construction periods (PERMDISP $F_{2,20}=2.56, p=$ 0.103). No indicator species were identified for the pre-dam construction period, but there were 13 species that had affinities with the period after dam construction (table 10). Several cyprinid minnows, including central stonerollers (Campostoma anomalum), ghost shiners (Notropis buchanni), sand shiners (Notropis stramineus), and suckermouth minnows (Phenacobius mirabilis), were strong indicators of post-dam construction fish assemblages (table 10). Western mosquitofish (Gambusia affinis) and inland silversides (Menidia beryllina) showed affinities for post-dam construction conditions. Two centrarchids, largemouth bass (Micropterus salmoides) and white crappie (Pomoxis annularis), were significant indicator species for the post-dam construction period. The slenderhead darter (Percina phoxocephala) was also associated with post-dam construction conditions in Bird Creek (table 10).

\section{Effects of Flow Alteration on Fish Assemblages}

Development of flow-ecology relationships is critical to setting management goals for protecting freshwater biodiversity in altered ecosystems (Poff and others, 2010; Poff and Zimmerman, 2010). Analyses of spatial datasets that represent hydrologic alteration gradients as well as temporal biological datasets spanning pre-and post-hydrologic alteration events aid in this process by identifying components of altered hydrologic regimes and other factors that influence biological change (Propst and Gido, 2004; Armstrong and others, 2010; Gido and others, 2010; Poff and Zimmerman, 2010; Taylor, 2010). Results from such studies can be used by water resource managers to help restore critical components of the flow regime while continuing to meet anthropogenic needs for water (Richter and others, 2003). The study of this report focused on relationships between flow alteration and fish assemblage structure and function, relying on a fish dataset with sites that represented different degrees of flow alteration, as well as two temporal fish datasets representing pre- and post-river impoundment environments. At the broad scale, fish assemblage and functional structure were associated with several flow metrics (Poff and Allan, 1995) but had stronger associations with regional factors, evidence that regional differences in flow regimes potentially influence fish assemblage structure (Gehrke and Harris, 2001). Likewise, patterns in functional group membership were associated with reference versus altered flows, but similar patterns were observed from east to west. Thus, the development of flow-ecology relationships needs to be stratified across these ecosystem types.

Although not presented in this report, we classified altered sites into three levels of alteration (low, moderate, high) based on the number and percentage exceeding the expected range of values. There were no clear relationships between increasing flow alteration and fish functional groups. A study of this type of relationship between degree of flow alteration and fish ecology could prove useful, but would be better served by a planned study with active data collection to control the level and location of fish sampling relative to alteration. The differences in fish assemblages and flow regime between the eastern and western portions of Oklahoma would be best served by separate studies of these areas. 
A previous study of Oklahoma fishes found that they are more sensitive to habitat degradation than water quality degradation (Jester and others, 1992), so efforts to identify specific instream habitat changes directly related to flow regime alteration in Oklahoma could enhance the results in this report. Fish species also can be used as indicators of flow alteration, as has been done with water quality in Great Lakes wetlands (Seilheimer and Chow-Fraser, 2007) and in this report with the ISA in Bird Creek. This method would take advantage of the greater distribution of fish collection data, as well as the relative ease of collecting fish samples compared with the 15 or more years of flow data needed to assess flow regime.

One hydrologic change that is clearly shown in our analysis of flow alteration is the shift to higher, more stable flows that are reflected by Turton and others (2009), as classified in group 43. Conditions in group 43 only occurred in a small group of only 6 streams in northeastern Oklahoma from the initial total of 88. We observed perennial flashy (42) and intermittent (44) streams undergoing significant changes to flow regime to group 43 in current flows. The impacts of this change are evident in the analysis of Bird Creek, which changed from an intermittent to a stable groundwater classification after the impoundment of Skiatook Lake. Interestingly, following the impoundment of Sardis Lake, the Kiamichi River did not shift from a perennial flashy stream to one with stable flows characteristic of group 43. An analysis of fish assemblage structure across a 17-year period associated with reservoir impoundment in these two river systems indicated that there were significant shifts in species composition for both sites. However, the degree to which reservoir impoundment altered downstream flow regimes within the study reaches was not consistent between the two river systems. The construction of Skiatook Lake within the Bird Creek river system significantly altered aspects of all five components of flow (magnitude, timing of occurrence, frequency of occurrence, duration of time, and rate of change in flow conditions), resulting in a change from a naturally intermittent stream flow regime to more stable flows, characteristic of streams in northeastern Oklahoma (Turton and others, 2009). In contrast, the Kiamichi River hydrologic regime downstream of Sardis Lake was relatively unaltered with modest declines in maximum flows and slight increases in number of reversals. This system retained the characteristics of a perennial flashy stream identified by Turton and others (2009). Despite this lack of identifiable change, there were still significant changes in fish assemblage structure within both systems across the 17-year period associated with reservoir construction, but species associated with these changes differed between the two systems. Several flow-dependent species as well as reservoir species, including largemouth bass, increased within the period of record associated with flow alteration in Bird Creek, a historically intermittent stream, whereas declines in two riverine-adapted fish coupled with an increase in largemouth bass were associated with the impoundment of Sardis Lake within the Kiamichi River basin. These contrasting responses of flow regimes and fish assemblages to reservoir impoundment within these the two river systems highlight the fact that linkages between reservoir impoundments, hydrologic alteration, and biological attributes are dependent on the ecological setting and associated natural hydrologic regimes of study systems.

Bird Creek lies in north-central Oklahoma and exhibits a historical flow regime with high flow variability and extended periods of extreme low flows, typical of streams draining the Great Plains region of North America (Poff and Ward, 1989; Dodds and others, 2004). Fishes of prairie streams have evolved behavioral and physiological mechanisms as well as life history traits to cope with variable and sometimes harsh conditions associated with dynamic hydrology (Matthews, 1987, 1988; Labbe and Fausch, 2000; Matthews and Marsh-Matthews, 2003). It is not surprising that there were no significant indicator species associated with Bird Creek fish 
assemblages during the pre-impoundment period because fish assemblage structure likely varies with stream flow across time in intermittent streams (Matthews and Marsh-Matthews, 2003). Higher flow conditions and loss of low- to no-flow periods associated with post-impoundment habitats corresponded with increases in frequency and abundance of fluvial-dependent species, including central stonerollers, sand shiners, suckermouth minnows, and slenderhead darters. Central stonerollers can occupy a wide variety of stream conditions ranging from intermittent headwater streams to downstream perennial reaches and adjust life history strategies to persist along fluvial gradients experienced in prairie streams (Spranza and Stanley, 2000). Fluvial habitats with perennial flow provide more predictable habitat conditions, which may confer more stable fish populations. Sand shiners are broadcast spawners that prefer flowing water over sand substrates, particularly in the presence of other Notropis sp. (Mueller and Pyron, 2011). Conditions downstream of reservoirs may provide other benefits to sand shiners, such as decreased turbidity, which has been shown to negatively impact feeding on terrestrial and aquatic insects by this species (Bonner and Wilde, 2002). Suckermouth minnows and slenderhead darters prefer fast flowing waters and require high-velocity areas during spring for spawning (Brewer and others, 2006). These two species seem to persist downstream of dams but are often extirpated upstream of reservoirs; however, spawning habitats may be impacted by flood control reservoirs due to impacts on the timing and magnitude of flows (Quist and others, 2005; Brewer and others, 2006). We also observed an increase in western mosquitofish, a species not generally associated with higher flows. Mosquitofish exhibit an opportunistic life history strategy characterized by small body size with early maturation, low fecundity per spawning event, and low juvenile survivorship (Winemiller and Rose, 1992; Hoeinghaus and others, 2007). This strategy is well adapted to fish occupying habitats that experience frequent and intense disturbance and likely confers an ability to monopolize and maintain higher abundances in highly variable shallow stream margin habitats associated with substantially more flow reversals in post-impoundment conditions.

Southeastern Oklahoma streams lie within the western extension of the Ozark Mountains and support perennial flow with a certain degree of flashiness. While impoundment of Sardis Lake did not have strong effects on long-term patterns in stream discharge, general increases in September median flows, low-flow duration, and number of reversals for 1976-1996 were associated with shifts in fish assemblage structure during the study period. However, these increases explained a small proportion of the variation in fish assemblage structure, and there were few significant indicator species for the pre- or post-impoundment periods.

Patterns in indicator species analysis suggest that factors associated with reservoir impoundment other than flow may have influenced changes in fish assemblage structure. We observed an increase in frequency and abundance in largemouth bass coupled with a decrease in spotted bass. The flow analysis results do not support altered hydrology as a primary mechanism for this shift, and this result may be due simply to increased largemouth bass abundance associated with stocking in Sardis Lake as well as Hugo Lake downstream. Additionally, reservoir-like conditions can occur during high flow periods within the stream reach due to backwater from Lake Hugo. This potential mechanism was not limited to the Kiamichi River site as we also observed higher frequency and abundance of inland silversides and largemouth bass in post-impoundment collections downstream of Skiatook Lake in Bird Creek. Shifts in largemouth bass frequency and abundance downstream of reservoirs may be due to lentic species having more generalist life history traits which provide certain advantages in flow-altered environments (Arthington and others, 2006). However, increases in largemouth bass abundance 
across two systems that differ in flow alteration suggest that their abundance may be more related to dispersal from introductions within the reservoir rather than flow requirements. Previous studies have demonstrated that upstream as well as regional patterns in fish assemblage structure are influenced by proximity to reservoir assemblages (Falke and Gido, 2006; Gido and others, 2010).

Quist and others (2005) observed introduced game fish species both upstream and downstream after construction of a reservoir. This may have been a mechanism for increased largemouth bass and forage fish frequency and abundance downstream of reservoirs in the current study. The distribution of inland silversides was historically limited to Atlantic and Gulf Coast waters and adjacent coastal portions of rivers. Inland silversides has been widely introduced in reservoirs of Midwestern States as forage for game fish and is responsible for large declines in brook silverside populations in Oklahoma (Gomez and Lindsay, 1972; McCormas and Drenner, 1982). While native to Oklahoma streams, largemouth bass populations were augmented through stocking of Skiatook reservoir immediately after impoundment. However, spotted bass populations increased in the early 1990s and displaced largemouth bass from much of their habitat (Long and Fisher, 2005). Factors influencing black bass habitat use within the reservoir (stocking, displacement) potentially influenced temporal patterns of frequency and occurrence of largemouth bass in downstream habitats of both systems.

Several studies have shown changes in fish assemblage structure associated with water resource development and reservoir operations (Bain and others, 1988; Bonner and Wilde, 2002; Marchetti and Moyle, 2001; Perkin and Bonner, 2011). Our analysis examines a temporal sequence of fish assemblage structure in response to reservoir construction in two different stream systems representing different ecological settings. However, other factors related to reservoirs, including altered thermal regimes due to hypolimnetic releases (Olden and Naiman, 2010) and proximity to reservoir habitats (Falke and Gido, 2006; Gido and others, 2010), may also influence fish assemblage structure in lotic environments. Additionally, while the biological datasets used in this study were reasonably long, these are temporal datasets of limited length. For example, in our Kiamichi River analysis, there was little change in long-term hydrologic patterns. Yet, within the period of fish sampling there were trends in several hydrologic variables that were correlated with fish assemblage structure.

The Kiamichi River is a well-studied system, and recent studies examining longer time trends have made some alarming observations. Drought conditions after the period of record that this study assessed, combined with flow management have resulted in serious dewatering of fluvial habitats and an associated decline in mussel densities with a shift in assemblage structure from thermally sensitive to tolerant species (Galbraith and others, 2010). This shift in mussel assemblages has important consequences for ecosystem function (Spooner and Vaughn, 2008; Vaughn, 2010). It is possible that fluvial fish species have also declined during this period. For this reason it is important that water management goals be developed by considering a range of variability approach that identifies natural flow regimes for dry, moderate, and wet periods to maintain key components of the natural flow regime (Richter and others, 2003). The results of this study indicate that interactions between flow regime and aquatic biota vary depending on ecological setting.

This study was limited by the low number of gaged locations with associated fish collections. Of these locations with streamflow and fish information, only a subset had a known reference period and could be used. We were unsuccessful at drawing a conclusion associated with a gradient of flow alteration, which may have been due to the types of streams in each class 
or from other factors impacting species other than flow alteration. The streams considered altered were from different ecoregions; thus, there may be biogeographical constraints on the biota that could confound the analysis with regards to altered flow regime.

\section{References Cited}

Anderson, M.J., 2001, A new method for non-parametric multivariate analysis of variance: Austral Ecology, v. 26, p. 32-46.

Anderson, M.J., 2006, Distance-based test for homogeneity of multivariate dispersions:

Biometrics, v. 62, no. 1, p. 245-253.

Armstrong, D.S., Richards, T.A., and Brandt, S.L., 2010, Preliminary assessment of factors influencing riverine fish communities in Massachusetts: U.S. Geological Survey Open-File Report 2010-1139, 43 p., accessed February 29, 2012, at http://pubs.usgs.gov/of/2010/1139/.

Arthington, A.H., Bunn, S.E., Poff, N.L., and Naiman, R.J., 2006, The challenge of providing environmental flow rules to sustain river ecosystems: Ecological Applications, v. 16, no. 4, p. 1311-1318.

Bain, M.B., Finn, J.T., and Booke, H.E., 1988, Streamflow regulation and fish community structure: Ecology, v. 69, no. 2, p. 382-392.

Bonner, T.H., and Wilde, G.R., 2002, Effects of turbidity on prey consumption by prairie steam fishes: Transactions of the American Fisheries Society, v. 131, p. 1203-1208.

Brewer, S.K., Papoulias, D.M., and Rabeni, C.F., 2006. Spawning habitat associations and selection by fishes in a flow regulated prairie river: Transactions of the American Fisheries Society, v. 135, no. 3, p. 763-778.

Clarke, K.R., 1993, Non-parametric multivariate analyses of changes in community structure: Austral Ecology, v. 18, no. 1, p. 117-143.

ConserveOnline, [undated], Indicators of hydrologic alteration (IHA)—Software for understanding hydrologic changes in ecologically-relevant terms: ConserveOnline, accessed November 1, 2009, at http://conserveonline.org/workspaces/iha.

Dodds, W.K., Gido, Keith, Whiles, M.R., Fritz, K.M., and Matthews, W.J., 2004, Life on the edge-The ecology of Great Plains prairie streams: Bioscience, v. 54, no. 3, p. 205-216.

Dufrêne, Marc, and Legendre, Pierre, 1997, Species assemblages and indicator species-The need for a flexible asymmetrical approach: Ecological Monographs, v. 67, no. 3, p. 345-366.

Environmental Research Systems Institute, Inc., [undated], ArcGIS-Mapping \& analysis for understanding our world: Environmental Research Systems Institute, Inc., accessed February 29, 2012, at http://www.esri.com/software/arcgis/index.html.

Esralew, R.A., 2010, Determination of baseline periods of record for selected streamflow-gaging stations in and near Oklahoma for use in modeling applications: U.S. Geological Survey Scientific Investigations Report 2010-5106, 65 p., accessed February 29, 2012, at http://pubs.usgs.gov/sir/2010/5106/.

Faith, D.P., and Norris, R.H., 1989., Correlation of environmental variables with patterns of distribution and abundance of common and rare freshwater macroinvertebrates: Biological Conservation, v. 50, nos. 1-4, p. 77-98.Falke, J.A., and Gido, K.B., 2006, Effects of reservoir connectivity on stream fish assemblages in the Great Plains: Canadian Journal of Fisheries and Aquatic Sciences, v. 63, no. 3, p. 480-493.

Fitzhugh, T.W., and Richter, B.D., 2004, Quenching urban thirst-Growing cities and their impacts on freshwater ecosystems: Bioscience, v. 54, no. 8, p. 741-754. 
Frimpong, E.A., and Angermeier, P.L., 2009, FishTraits-A database of ecological and life history traits of freshwater fishes in the United States: Fisheries, v. 34, no. 10, p. 487-495.

Galbraith, H.S., Spooner, D.E., and Vaughn, C.C., 2010, Synergistic effects of regional climate patterns and local water management on freshwater mussel communities: Biological Conservation, v. 143, p. 1175-1183.

Gehrke, P.G., and Harris, J.H., 2001, Regional-scale effects of flow regulation on lowland riverine fish communities in New South Wales, Australia: River Research and Management, v. 17, nos. 4-5, p. 369-391.

Gido, K.B., Dodds, W.K., and Eberle, M.E., 2010, Retrospective analysis of fish community change during a half-century of landuse and streamflow changes: Journal of the North American Benthological Society, v. 29, no. 3, p. 970-987.

Goldstein, R.M., and Simon, T.P., 1998, Toward a united definition of guild structure for feeding ecology of North American freshwater fishes, in Simon, T.P., ed., Assessing the sustainability and biological integrity of water resources using fish communities: Boca Raton, Fla., CRC Press, p. 123-202.

Gomez, Ricardo, and Lindsay, H.L., Jr., 1972, Occurrence of the Mississippi silversides, Menidia audens (Hay), in Keystone Reservoir and the Arkansas River: Proceedings of the Oklahoma Academy of Sciences, v. 52, p. 16-18.

Gotelli, N.J., and Ellison, A.M., 2004, A Primer of Ecological Statistics: Sunderland, Mass., Sinauer Associates Inc.,

Henriksen, J.A., Heasley, John, Kennen, J.G., and Nieswand, Steven, 2006, Users’ manual for the hydroecological integrity assessment process software (including the New Jersey assessment tools): U.S. Geological Survey Open-File Report 2006-1093, 71 p., accessed February 29, 2012, at http://www.fort.usgs.gov/Products/Publications/21598/21598.pdf.

Hoeinghaus, D.J., Winemiller, K.O., and Birnbaum, J.S., 2007, Local and regional determinants of stream fish assemblage structure-Inferences based on taxonomic vs. functional groups: Journal of Biogeography, v. 34, p. 324-338.

Jester, D.B., Echelle, A.A., Matthews, W.J., Pigg, Jimmie, Scott, C.M., and Collins, K.D., 1992, The fishes of Oklahoma, their gross habitats, and their tolerance of degradation in water quality and habitat: Proceedings of the Oklahoma Academy of Science, v. 72, p. 7-19.

Kennard, Mark J., Pusey, Bradley J., Olden, Julian D., Mackay, Stephen J., Stein, Janet L, Marsh Nick, 2010, Classification of natural flow regimes in Australia to support environmental flow management: Freshwater Biology v. 55, no. 1, p. 171-193.Labbe, T.R., and Fausch, K.D., 2000, Dynamics of intermittent stream habitat regulate persistence of a threatened fish at multiple scales: Ecological Applications, v. 10, no. 6, p. 1774-1791.

Long, J.M., and Fisher, W.L., 2005, Distribution and abundance of black bass in Skiatook Lake, Oklahoma, after introduction of smallmouth bass and a liberalized harvest regulation on spotted bass: North American Journal of Fisheries Management, v. 25, p. 49-56.

Marchetti, M.P., and Moyle, P.B., 2001, Effects of flow regime on fish assemblages in a regulated California stream: Ecological Applications, v. 11, no. 2, p. 530-539.

Matthews, Ruth, and Richter, B.D., 2007, Application of the indicators of hydrologic alteration software in environmental flow setting: Journal of the American Water Resources Association v. 43, no. 6, p. 1400-1413.

Matthews, W.J., 1987, Geographic variation in Cyprinella lutrensis (pisces: Cyprinidae) in the United States, with notes on Cyprinella lepida: Copeia, no. 3, p. 616-637. 
Matthews, W.J., 1988, North American prairie streams as systems for ecological study: Journal of the North American Benthological Society, v. 7, no. 4, p. 387-409.

Matthews, W.J., and Marsh-Matthews, Edie, 2003, Effects of drought on fish across axes of space, time and ecological complexity: Freshwater Biology v. 48, no. 7, p. 1232-1253.

McCormas, S.R., and Drenner, R.W., 1982, Species replacement in a reservoir fish community - Silverside feeding mechanisms and competition: Canadian Journal of Fisheries and Aquatic Science, v. 39, p. 815-821.

McCune, Bruce, and Grace, J.B., 2002, Analysis of ecological communities: Gleneden Beach, Oreg., MjM Software Design, 304 p.

Minchin, P.R., 1987, An evaluation of the relative robustness of techniques for ecological ordination: Vegetation, v. 69, p. 89-107.

Mueller, Robert, Jr., and Pyron, Mark, 2009, Substrate and current velocity preferences of spotfin shiner (Cyprinella spiloptera) and sand shiner (Notropis stramineus) in artificial streams: Journal of Freshwater Ecology, v. 24, p. 239-245.

NatureServe, 2009, NatureServe explorer-An online encyclopedia of life (version 7.1):

NatureServe, accessed May 21, 2010, at http://www.natureserve.org/explorer/.

Oksanen, Jari, Blanchet, F.G., Kindt, Roeland, Legendre, Pierre, Minchin, P.R., O’Hara, R.B., Simpson, G.L., Solymos, Peter, Stevens, M.H.H., and Wagner, Helene, 2010, VeganCommunity ecology package (version 1.17-3): The Comprehensive R Archive Network, accessed February 29, 2012, at http://cran.at.r-project.org/web/packages/vegan/index.html.

Olden, J.D., and Naiman, R.J., 2010, Incorporating thermal regimes into environmental flows assessments-Modifying dam operations to restore freshwater ecosystem integrity: Freshwater Biology, v. 55, p. 86-107.

Olden, Julian D., and Poff, N.L., 2003, Redundancy and the choice of hydrologic indices for characterizing streamflow regimes: River Research and Applications, v. 19, p. 101-121.

Peck, J.E., 2010, Multivariate analysis for community ecologists-Step-by-step using PC-ORD: MjM Software Design, 162 p.

Perkin, J.S., and Bonner, T.H., 2011, Long-term changes in flow regime and fish assemblage composition in the Guadalupe and San Marcos rivers of Texas: River Research and Applications, v. 27, no. 5, p. 566-579.

Poff, N.L., Allan, J.D., Bain, M.B., Karr, J.R., Prestegaard, K.L., Richter, B.D., Sparks, R.E., and Stromberg, J.C., 1997, The natural flow regime: Bioscience, v. 47, no. 11, p. 769-784.

Poff, N.L., and Allan, J.D., 1995, Functional-organization of stream fish assemblages in relation to hydrological variability: Ecology, v. 76, no. 2, p. 606-627.

Poff, N.L., and Ward, J.V., 1989, Implications of streamflow variability and predictability for lotic community structure-A regional analysis of streamflow patterns: Canadian Journal of Fisheries and Aquatic Sciences, v. 46, p. 1805-1818.

Poff, N.L., and Zimmerman, J.K.H., 2010, Ecological responses to altered flow regimes-A literature review to inform the science and management of environmental flows: Freshwater Biology, v. 55, p. 194-205.

Poff, N.L., Olden, J.D., Merrit, D.M., and Pepin, D.M., 2007, Homogenization of regional river dynamics by dams and global biodiversity implications: Proceedings of the National Academy of Sciences, v. 104, no. 14, p. 5732-5737.

Poff, N.L., Richter, B.D., Arthington, A.H., Bunn, S.E., Naiman, R.J., Kendy, Eloise, Acreman, Mike, Apse, Colin, Bledsoe, B.P., Freeman, M.C., Henriksen, James, Jacobson, R.B., Kennen, J.G., Merritt, D.M., O’Keeffe, J.H., Olden, J.D., Rogers, Kevin, Tharme, R.E., and Warner, 
Andrew, 2010, The ecological limits of hydrologic alteration (ELOHA) - A new framework for developing regional environmental flow standards: Freshwater Biology, v. 55, no. 1, p. 147-170.

Postel, Sandra, and Richter, Brian, 2003, Rivers for life-Managing water for people and nature: Washington, D.C., Island Press, 220 p.

Propst, D.L, and Gido, K.B., 2004, Responses of native and nonnative fishes to natural flow regime mimicry in the San Juan River: Transactions of the American Fisheries Society, v. 133, p. 922-931.

Quist, M.C., Hubert, W.A., and Rahel, F.J., 2005, Fish assemblage structure following impoundment of a Great Plains river: Western North American Naturalist, v. 65, no. 1, p. 5363.

R Core Development Team, 2010, R-A language and environment for statistical computing: Vienna, Austria, R Foundation for Statistical Computing.

Richter, Brian D., Baumgartner, Jeffery V., Wigington, Robert, Braun, David P., 1997, How much water does a river need?: Freshwater Biology, v. 37, p. 231-249.

Richter, Brian D., Baumgartner, Jeffery V., Powell, Jennifer, and Braun, David P, 1996, A method for assessing hydrologic alteration within ecosystems: Conservation Biology, v.10, no. 4, p. 1163-1174.

Richter, B.D., Mathews, Ruth, Harrison, D.L., and Wigington, Robert, 2003, Ecological sustainable water management-Managing river flows for ecological integrity: Ecological Applications v. 13, no. 1, p. 206-224.

Rosenberg, D.M., McCully, Patrick, and Pringle, C.M., 2000, Global-scale environmental effects of hydrological alterations-Introduction: Bioscience, v. 50, no. 9, p. 746-751.

SAS Institute Inc., [undated], JMP ${ }^{\circledR}$ statistical discovery software: SAS Institute Inc., accessed February 29, 2012, at www.jmp.com/software/.

Seilheimer, T.S., and Chow-Fraser, P., 2007, Application of the wetland fish index to northern Great Lakes marshes with emphasis on Georgian Bay coastal wetlands: Journal of Great Lakes Research v. 33, suppl. 3, p. 154-171.

Spooner, D.E., and Vaughn, C.C., 2008, A trait-based approach to species’ roles in stream ecosystems-Climate change, community structure, and material cycling: Oecologia, v. 158, no. 2, p. 307-317.

Spranza, J.J., and Stanley, E.H., 2000, Condition, growth, and reproductive styles of fishes exposed to different environmental regimes in a prairie drainage: Environmental Biology of Fishes, v. 59, no. 1, p. 99-109.

Taylor, C.M., 2010, Covariation among plains stream assemblages, flow regimes, and patterns of water use, in Gido, K.B., and Jackson, D.A., eds., Community ecology of stream fishesConcepts, approaches, and techniques: American Fisheries Society Symposium 73, Bethesda, Md., p. 447-459.

Turton, Don, Fisher, Bill, Seilheimer, T.S., and Esralew, R.A., 2009, An assessment of environmental flows for Oklahoma-Final report: Stillwater, Okla., Oklahoma Water Resources Research Institute, Oklahoma State University, 58 p., accessed November 1, 2011, at http://environ.okstate.edu/OWRRI/files/2008_TurtonFisher_FinalReport.pdf.

U.S. Geological Survey, [undated], National hydrologic assessment tool (NATHAT): U.S. Geological Survey, accessed February 29, 2012, at http://www.fort.usgs.gov/Products/Software/NATHAT/. 
Vaughn, C.C., 2010, Biodiversity losses and ecosystem function in freshwaters-Emerging conclusions and research directions: Bioscience, v. 60, p. 25-35.

Winemiller, K.O., and Rose, K.A., 1992, Patterns of life-history diversification in North American fishes-Implications for population regulation: Canadian Journal of Fisheries and Aquatic Science, v. 49, no. 10, p. 2196-2218. 


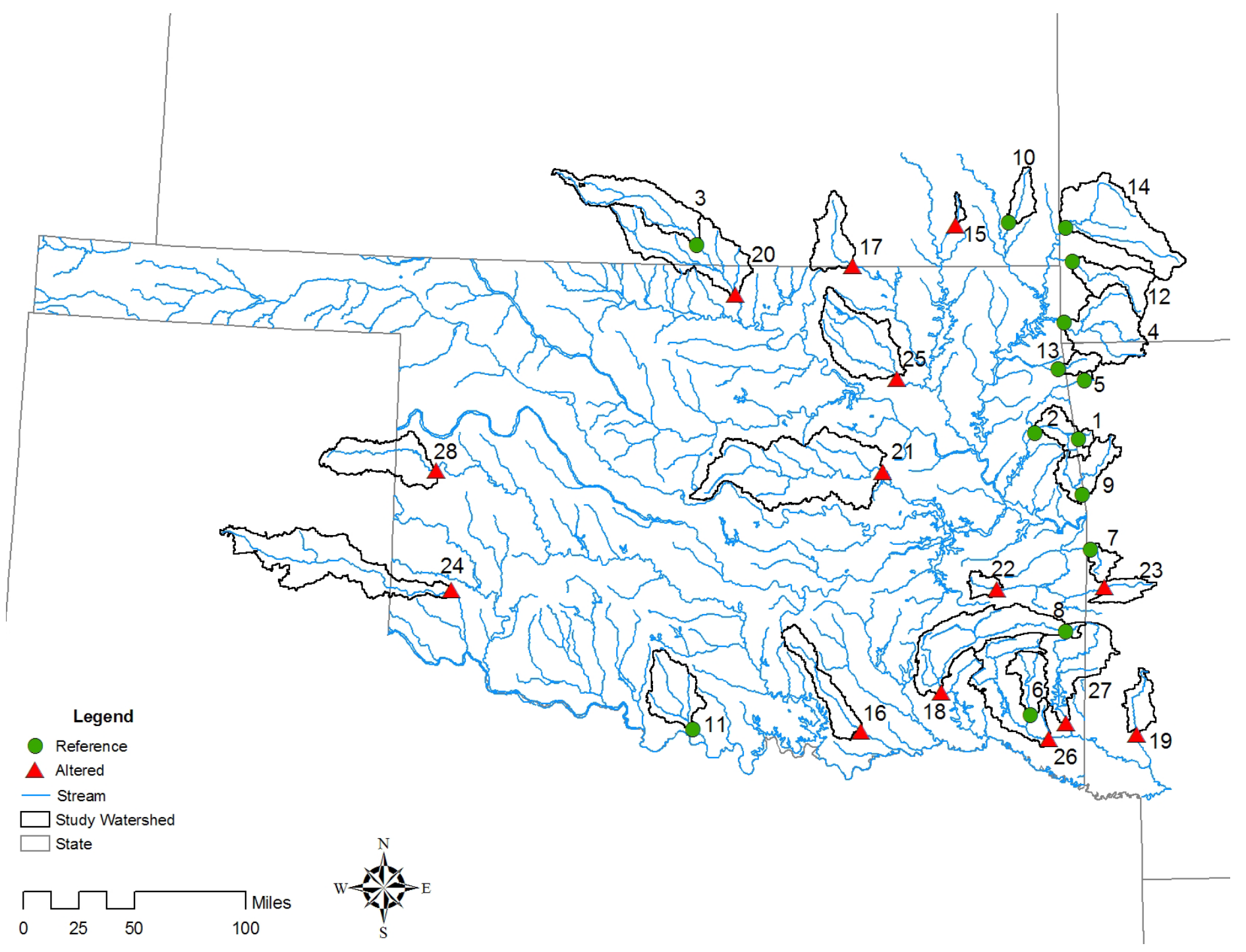

Figure 1. Map showing streamgage location and contributing watersheds for reference and altered sites in Oklahoma. Numbers next to streamgage symbols correspond to streamgage names in table 2. Digital data from U.S. Geological Survey, U.S. Environmental Protection Agency, and Oklahoma Water Resource Board, various scales. Gage locations and gage watersheds developed by authors. Projection is Geographic Coordinate System (GCS) North American 1927. Horizontal datum is North American Datum of 1927, Albers conical projection. Map created by Titus Seilheimer. 
A)

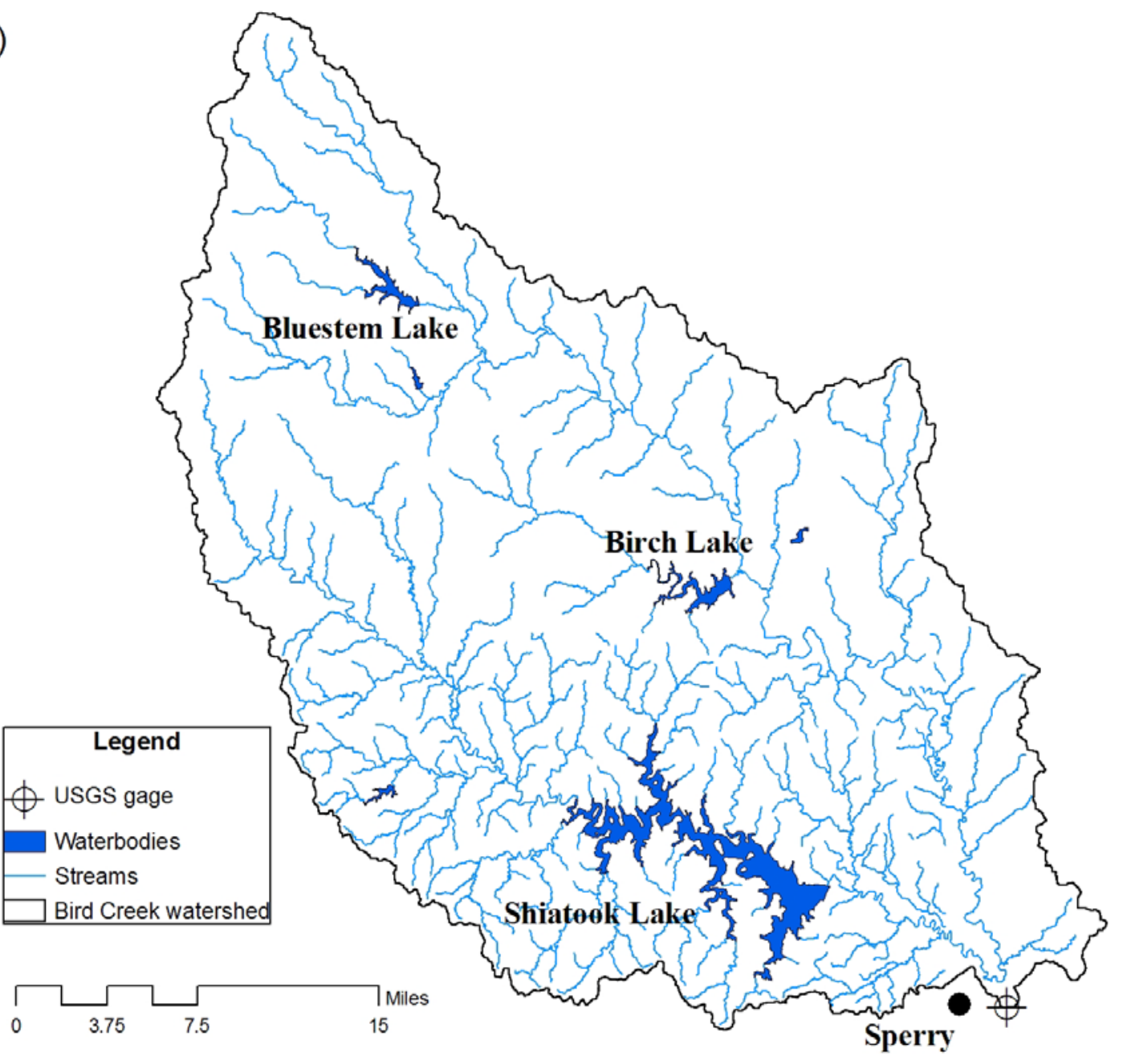

. 
B)

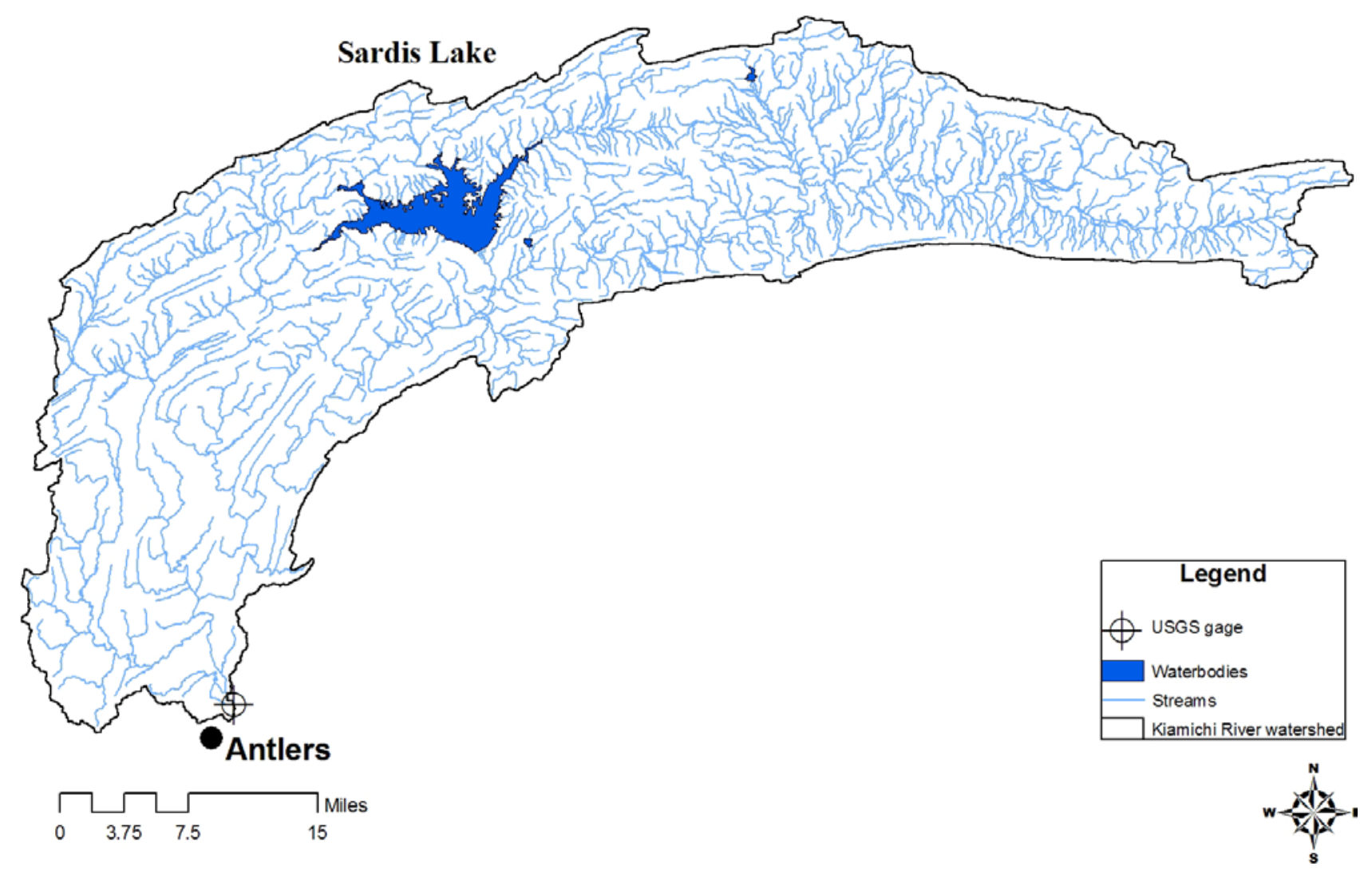

Figure 2. Map of the watershed on A, Bird Creek and B, Kiamichi River, Oklahoma. Sampling site on Bird Creek is in relation to U.S. Geological Survey (USGS) streamgage 07177500 near Sperry, Okla., Birch Lake, and Skiatook Lake; sampling site on Kiamichi River is in relation to USGS streamgage 07336200 near Antler, Okla., and Sardis Lake. Stream data from U.S. Environmental Protection Agency and water body data from the Oklahoma Water Resources Board, various scales. Gage locations and gage watersheds developed by authors. Projection is Geographic Coordinate System (GCS) North American 1927. Horizontal datum is North American Datum of 1927, Albers conical projection. Map created by Titus Seilheimer. 


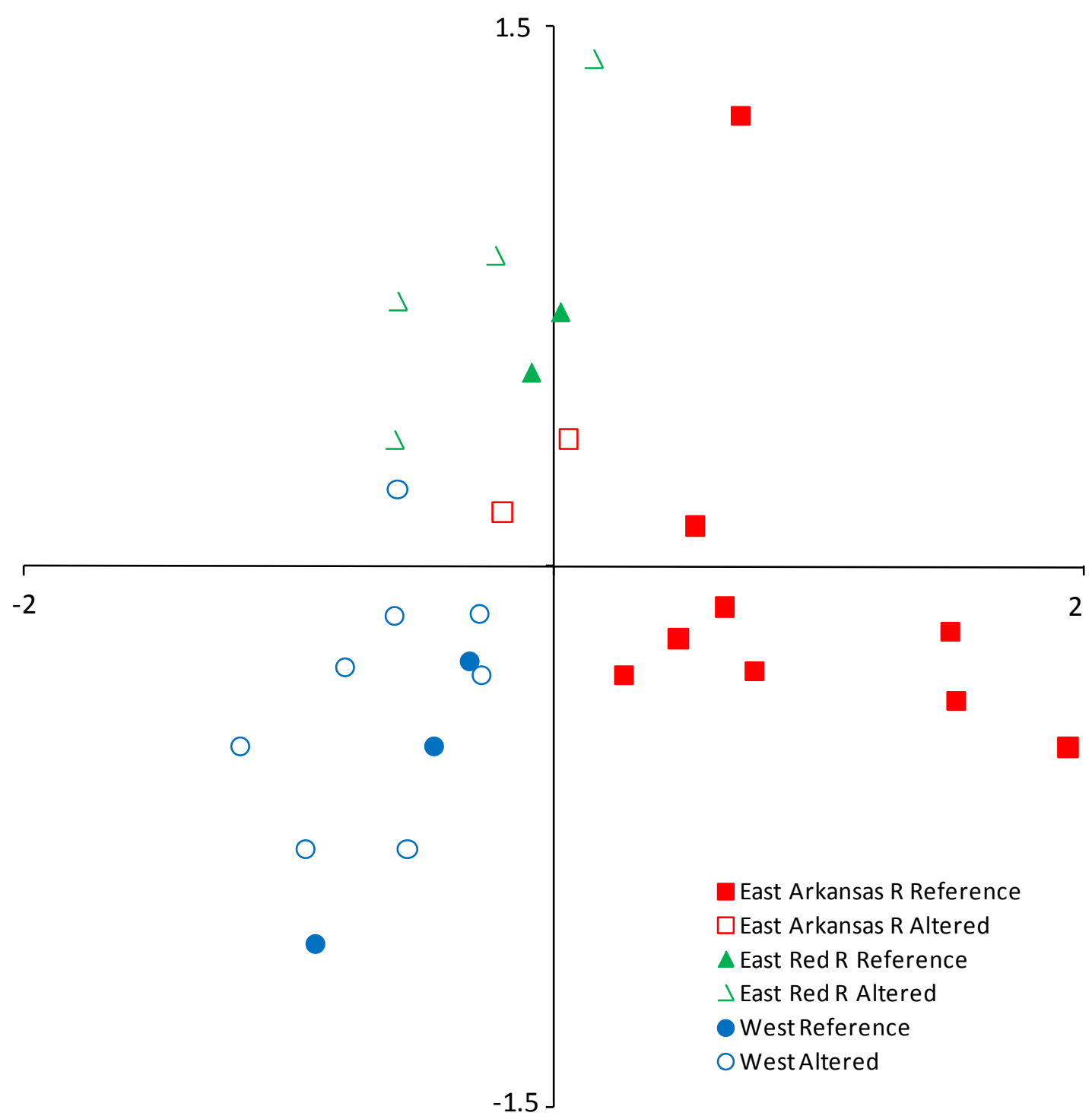

Figure 3. Ordination biplot from nonmetric multidimensional scaling (NMS; Jaccard) of species presence for fishes associated with 28 streamgages on reference and altered streams in Oklahoma. The x-axis is NMS 1, and the y-axis is NMS 2. 


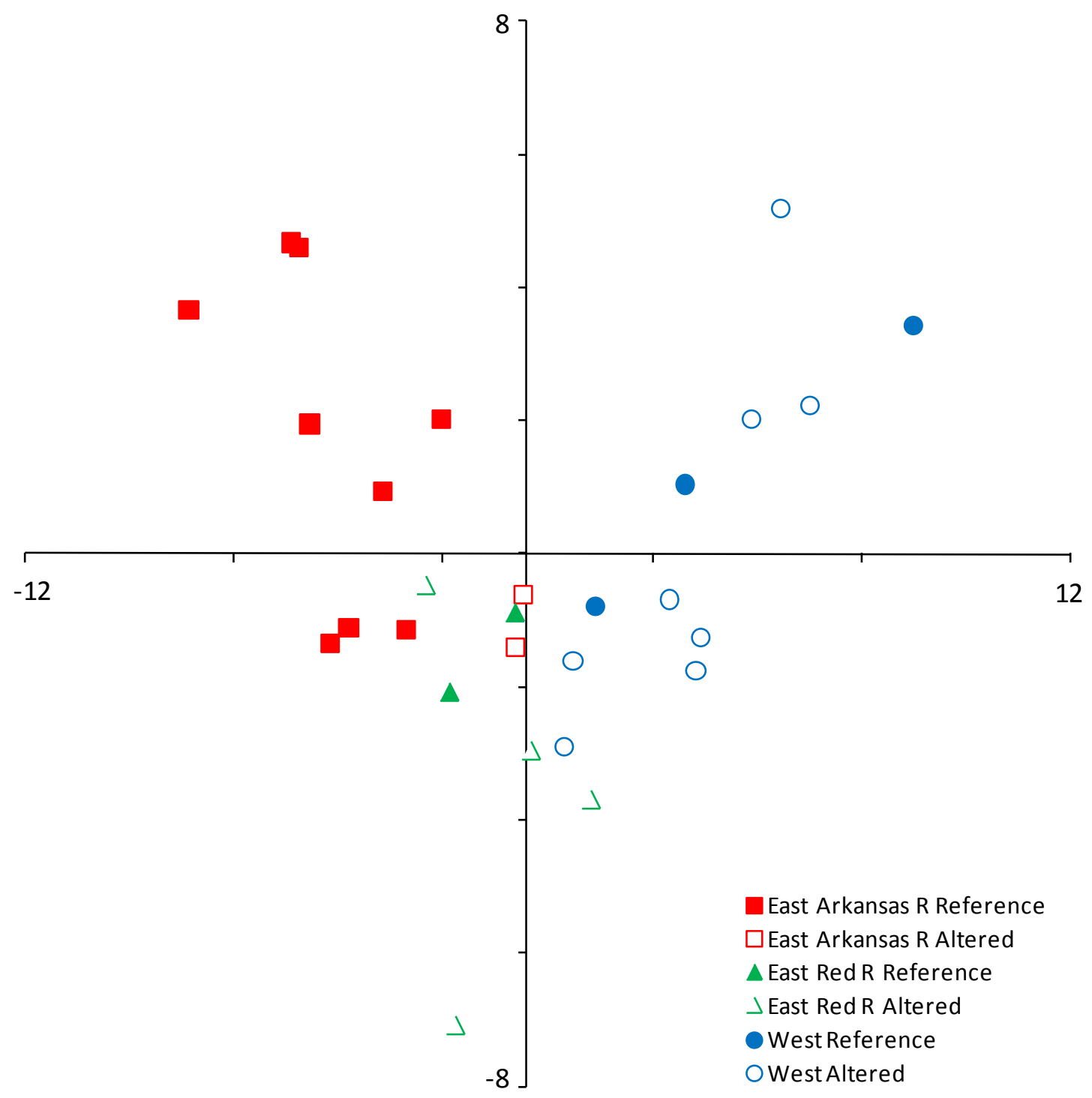

Figure 4. Ordination biplot from principal components (PC) analysis of proportion of functional groups for 28 streamgages on reference and altered streams in Oklahoma. The x-axis is PC1, and the $y$-axis is PC2. 


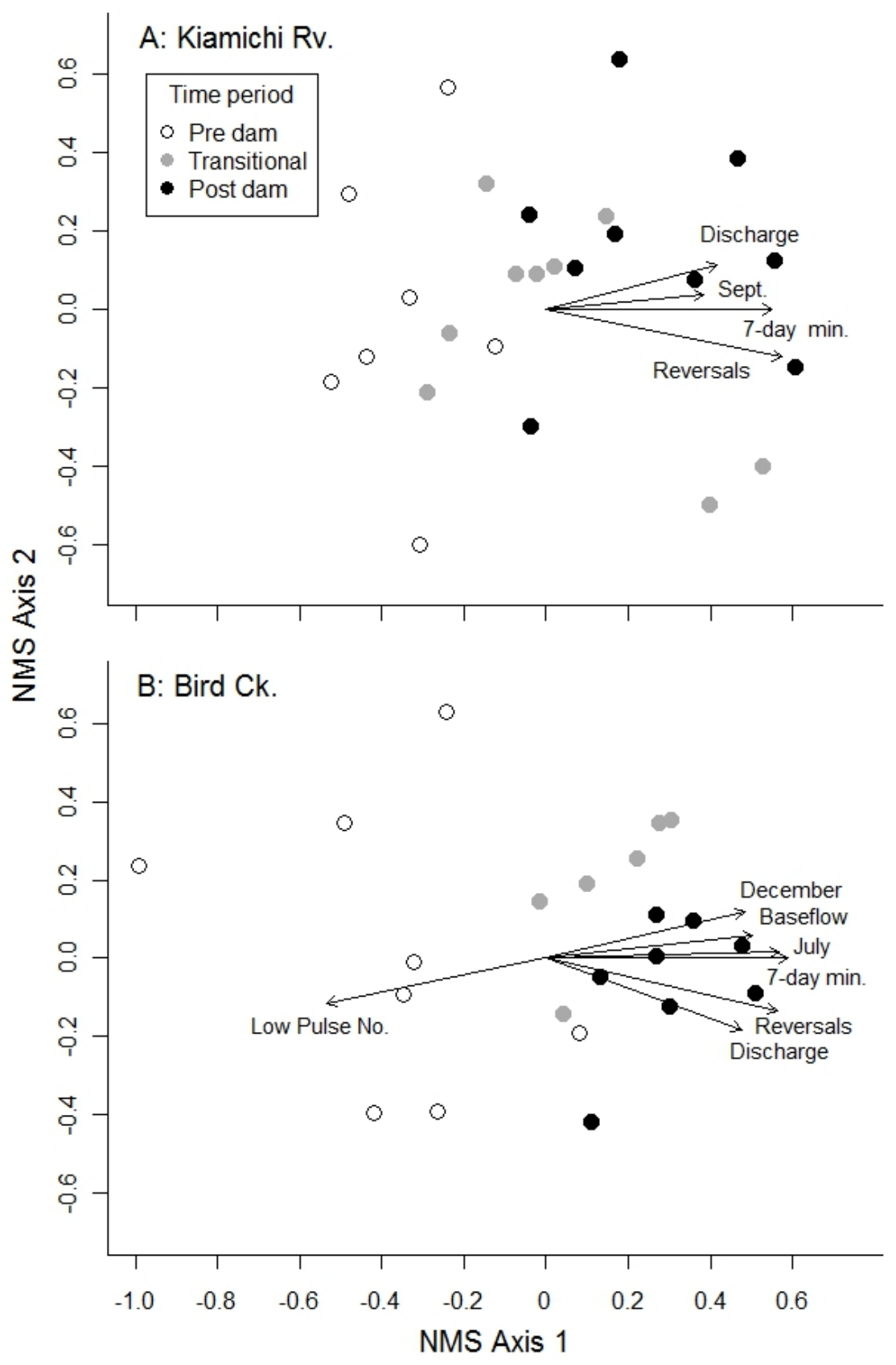

Figure 5. Charts showing nonmetric multidimensional scaling (NMS) ordination based on fish species composition for sampling events conducted during the early summer over 18 years at one location on $A$, the Kiamichi River (stress $=15.08$ ) and B, Bird Creek (stress $=13.07$ ), Oklahoma. The collection sites lie downstream of Sardis Lake on the Kiamichi River and downstream of Birch and Skiatook Lakes on Bird Creek, which were formed by impoundments in 1977 and 1982, respectively. NMS axes 1 and 2 represent ecological distances between sites based on differences in their species composition. Open symbols indicate pre-dam sampling events, whereas solid symbols represent post-dam sampling events divided into transitional (grey), and post-dam construction (black) periods for the two river systems. Please refer to text for years associated with each period. Arrows indicate direction and magnitude of correlations between nonmetric multidimensional scaling scores and hydrologic parameters calculated with indicators of hydrologic alteration analysis (table 9). 

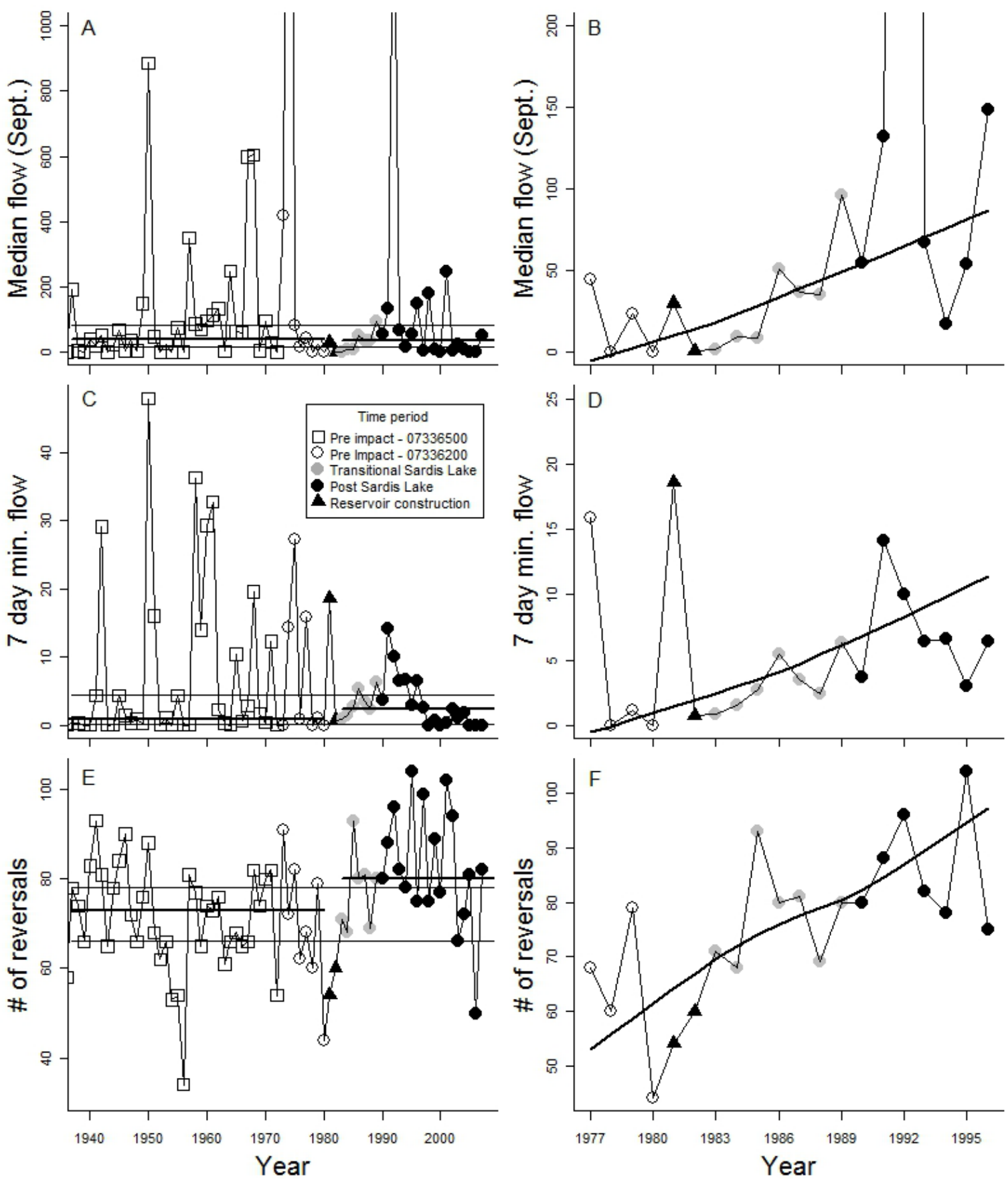

Figure 6. Chart showing annual variation in three hydrologic parameters that were significantly correlated with differences in fish assemblage structure (fig. 7A, table 9) in the Kiamichi River near Antlers, Oklahoma. Parameters include $A$ and $B$, median flows for September; $C$ and $D$, annual 7-day minimum (min.) flow; and $E$ and $F$, number (\#) of flow reversals per year. Each parameter includes plots of period of record $(A, C, E)$ followed by record associated with fish data $(B, D, F)$. Thin horizontal lines represent range of variation for the period before the construction of the impoundment, and thick horizontal lines represent median values for the periods before the construction of the impoundment and after the construction of the Sardis Lake impoundment. Smoothers (B, D, F) are based on locally weighted regression (LOWESS). All flow data are presented in cubic feet per second. 

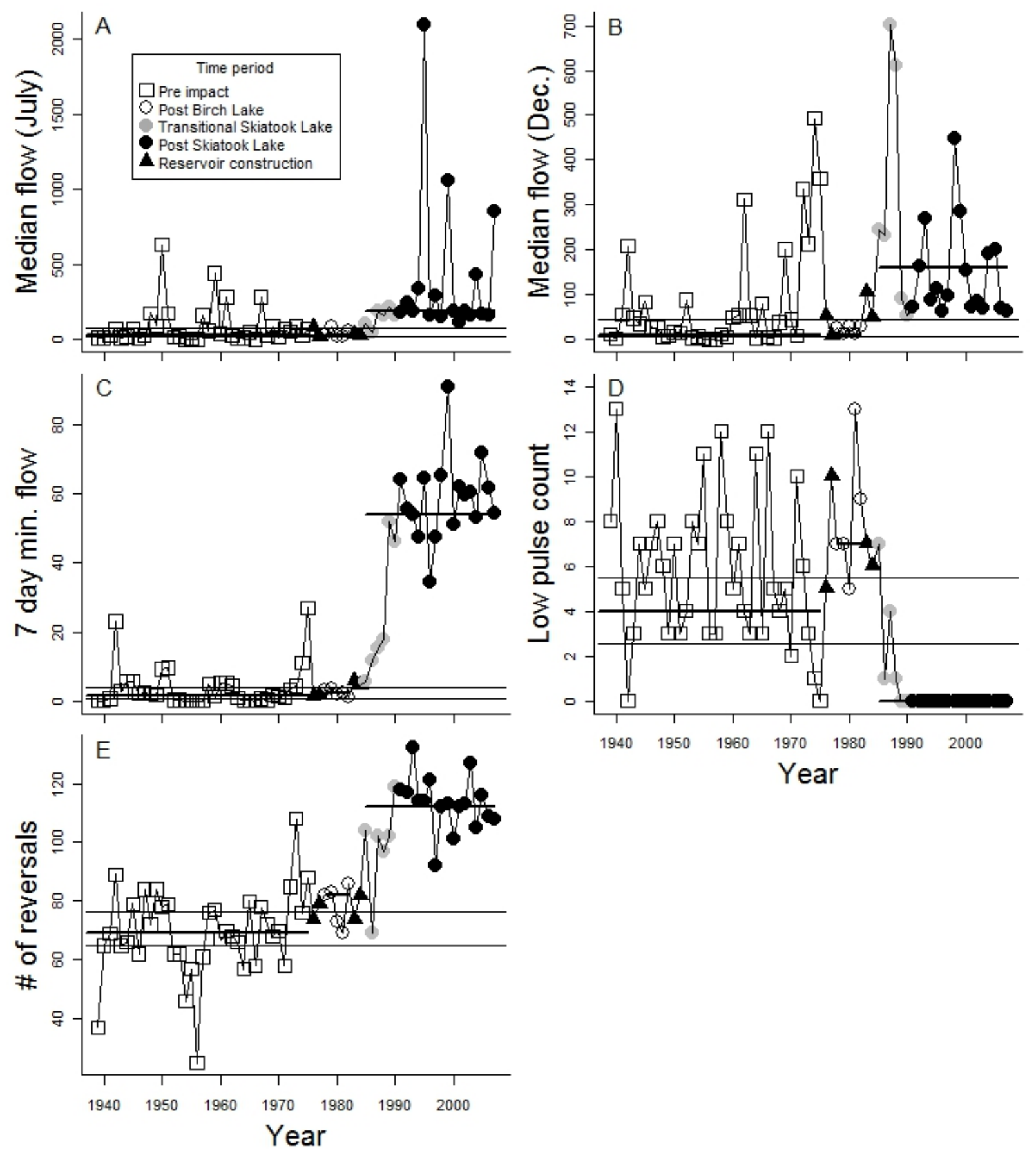

Figure 7. Charts showing annual variation in five hydrologic parameters that were significantly correlated with differences in fish assemblage structure (fig. 7B, table 9) in Bird Creek near Sperry, Oklahoma. Parameters include $A$, median flow for July; $B$, median flow for December; $C$, annual 7-day minimum (min.) flow; $D$, number of low pulses per year; and $E$, number (\#) of flow reversals per year. Thin horizontal lines represent range of variation for period before the construction of the impoundment, and thick horizontal lines represent median values for the periods before construction of the impoundment and after construction of the Birch Lake and Skiatook Lake impoundments. All flow data are presented in cubic feet per second. 
Table 1. Flow indices used in a biological assessment of flows of 28 streams in Oklahoma.

[ $\mathrm{ft}^{3} / \mathrm{s}$, cubic feet per second; $\mathrm{ft}^{3} / \mathrm{s} / \mathrm{mi}^{2}$, cubic feet per second per square mile; $\mathrm{ft}^{3} / \mathrm{s} / \mathrm{d}$, cubic feet per second per day; \%, percent]

\begin{tabular}{|c|c|c|c|}
\hline Code & Hydrologic index & Units & Definition \\
\hline \multicolumn{4}{|c|}{ Magnitude } \\
\hline MA01 & Mean daily flows & $\mathrm{ft}^{3} / \mathrm{s}$ & Mean daily flows. \\
\hline MA04 & Variability in daily flows 1 & $\%$ & $\begin{array}{l}\text { Coefficient of variation of the logs in daily flows corresponding to the }\{5 \text { th, } \\
\text { 10th, 15th, ..., 85th, 90th, 95th }\} \text { percentiles. }\end{array}$ \\
\hline MA28 & Variability in May flows & $\%$ & Coefficient of variation in monthly flows for May. \\
\hline ML01 & Mean minimum January flows & $\mathrm{ft}^{3} / \mathrm{s}$ & Mean minimum monthly flow for January. \\
\hline ML09 & Mean minimum September flows & $\mathrm{ft}^{3} / \mathrm{s}$ & Mean minimum monthly flow for September. \\
\hline MH04 & Mean maximum April flows & $\mathrm{ft}^{3} / \mathrm{s}$ & Mean of the maximum monthly flows for April. \\
\hline MH14 & Median of annual maximum flows & Dimensionless & $\begin{array}{l}\text { Median of the highest annual daily flow divided by the median annual daily flow } \\
\text { averaged across all years. }\end{array}$ \\
\hline MH20 & Specific mean annual maximum flows & $\mathrm{ft}^{3} / \mathrm{s} / \mathrm{mi}^{2}$ & Mean annual maximum flows divided by catchment area. \\
\hline \multicolumn{4}{|c|}{ Frequency } \\
\hline FL03 & Frequency of low flow spells & Events per year & $\begin{array}{l}\text { Total number of low flow spells (threshold equal to } 5 \% \text { of mean daily flow) } \\
\text { divided by the record length in years. }\end{array}$ \\
\hline FH01 & High flood pulse count 2 & Events per year & $\begin{array}{l}\text { Mean number of high pulse events, where the 75th percentile is the high pulse } \\
\text { threshold. }\end{array}$ \\
\hline FH04 & High flood pulse count 1 & $\mathrm{~d} / \mathrm{yr}$ & $\begin{array}{l}\text { Mean number of days per year above the upper threshold (defined as } 7 \text { times } \\
\text { median daily flow), and the value is represented as an average instead of a } \\
\text { tabulated count. }\end{array}$ \\
\hline FH05 & Flood frequency 1 & Events per year & $\begin{array}{l}\text { Mean number of high flow events per year using an upper threshold of } 1 \text { times } \\
\text { median flow over all years. }\end{array}$ \\
\hline \multicolumn{4}{|c|}{ Duration } \\
\hline DL03 & Annual minima of 7-day means of daily discharge & $\mathrm{ft}^{3} /$ second & Magnitude of minimum annual flow of 7-day mean daily discharge. \\
\hline DL05 & Annual minima of 90-day means of daily discharge & $\mathrm{ft}^{3} /$ second & Magnitude of minimum annual flow of 90-day mean daily discharge. \\
\hline DL18 & Number of zero-flow days & $\mathrm{d} / \mathrm{yr}$ & Mean annual number of days having zero daily flow. \\
\hline DH07 & $\begin{array}{l}\text { Variability in annual maxima of 3-day means of } \\
\text { daily discharge }\end{array}$ & $\%$ & Coefficient of variation in the 3-day moving average flows. \\
\hline DH10 & $\begin{array}{l}\text { Variability in annual maxima of 90-day means of } \\
\text { daily discharge }\end{array}$ & $\%$ & Coefficient of variation in the 90-day moving average flows. \\
\hline DH15 & High flow pulse duration & $\mathrm{d} / \mathrm{yr}$ & Mean duration of FH1 (high flood pulse count 1). \\
\hline DH21 & High flow duration 1 & Days & $\begin{array}{l}\text { Average duration of flow events with flows above a threshold equal to the 25th } \\
\text { percentile value for the entire set of flows. }\end{array}$ \\
\hline & & & 27 \\
\hline
\end{tabular}




\begin{tabular}{|c|c|c|c|}
\hline Code & Hydrologic index & Units & Definition \\
\hline $\begin{array}{l}\text { DH23 } \\
\end{array}$ & Flood duration 1 & Days & $\begin{array}{l}\text { Mean annual number of days that flows remain above the flood threshold } \\
\text { averaged across all years. }\end{array}$ \\
\hline \multicolumn{4}{|c|}{ Timing } \\
\hline TA01 & Constancy & Dimensionless & See Colwell (1974). \\
\hline TL01 & Julian date of annual minimum & Julian days & The mean Julian date of the 1-day annual minimum flow over all years. \\
\hline TH01 & Julian date of annual maximum & Julian days & The mean Julian date of the 1-day annual maximum flow over all years. \\
\hline \multicolumn{4}{|c|}{ Rate of change } \\
\hline RA03 & Fall rate & $\mathrm{ft}^{3} / \mathrm{s} / \mathrm{d}$ & Mean rate of negative changes in flow from one day to the next. \\
\hline RA05 & No day rises & Dimensionless & Ratio of days where the flow is higher than the previous day. \\
\hline RA07 & Change of flow & $\mathrm{ft}^{3} / \mathrm{s} / \mathrm{d}$ & $\begin{array}{l}\text { Median of difference between natural logarithm of flows between two } \\
\text { consecutive days with decreasing flow. }\end{array}$ \\
\hline
\end{tabular}


Table 2. Streamgages used in a biologic assessment of the flows of 28 streams in Oklahoma, [Streamgage number corresponds to numbers in figure 1. HIP, hydroecological integrity assessment process; no., number; $\mathrm{mi}^{2}$, square miles. HIP classifications are from Turton and others (2009)]

\begin{tabular}{|c|c|c|c|c|c|c|c|}
\hline $\begin{array}{c}\text { Gage } \\
\text { no. }\end{array}$ & $\begin{array}{l}\text { Streamgage } \\
\text { code }\end{array}$ & Gage name & $\begin{array}{c}\text { HIP } \\
\text { group }\end{array}$ & $\begin{array}{l}\text { Alteration } \\
\text { status }\end{array}$ & Latitude & Longitude & $\begin{array}{c}\text { Basin } \\
\text { size } \\
\left(\mathrm{mi}^{2}\right)\end{array}$ \\
\hline 1 & 07196900 & Baron Fork at Dutch Mills, Ark. & 42 & Reference & 35.88 & -94.49 & 42.2 \\
\hline 2 & 07197000 & Baron Fork at Eldon, Okla. & 41 & Reference & 35.92 & -94.84 & 319.7 \\
\hline 3 & 07151500 & Chickaskia River near Corbin, Ks. & 41 & Reference & 37.13 & -97.60 & 833.6 \\
\hline 4 & 07189000 & Elk River near Tiff City, Mo. & 43 & Reference & 36.63 & -94.59 & 872.7 \\
\hline 5 & 07195800 & Flint Creek at Springtown, Ark. & 41 & Reference & 36.26 & -94.43 & 15.1 \\
\hline 6 & 07337900 & Glover River near Glover, Okla. & 42 & Reference & 34.10 & -94.90 & 328.6 \\
\hline 7 & 07249400 & James Fork near Hackett, Ark. & 42 & Reference & 35.16 & -94.41 & 150.5 \\
\hline 8 & 07335700 & Kiamichi River near Big Cedar, Okla. & 42 & Reference & 34.64 & -94.61 & 40.7 \\
\hline 9 & 07249985 & Lee Creek near Short, Okla. & 42 & Reference & 35.52 & -94.46 & 445.3 \\
\hline 10 & 07184000 & Lightning Creek near McCune, Ks. & 44 & Reference & 37.28 & -95.03 & 201 \\
\hline 11 & 07315700 & Mud Creek near Courtney, Okla. & 44 & Reference & 34.00 & -97.57 & 589.3 \\
\hline 12 & 07187000 & Shoal Creek above Joplin, Mo. & 43 & Reference & 37.02 & -94.52 & 438.5 \\
\hline 13 & 07191220 & Spavinaw Creek near Sycamore, Okla. & 41 & Reference & 36.33 & -94.64 & 135 \\
\hline 14 & 07186000 & Spring River near Waco, Mo. & 43 & Reference & 37.25 & -94.57 & $1,188.1$ \\
\hline 15 & 07170700 & Big Hill Creek near Cherryvale, Ks. & 44 & Altered & 37.27 & -95.47 & 37.8 \\
\hline 16 & 07332500 & Blue River near Blue, Okla. & 41 & Altered & 34.00 & -96.24 & 489.8 \\
\hline 17 & 07172000 & Caney River near Elgin, Ks. & 42 & Altered & 37.00 & -96.32 & 439.6 \\
\hline 18 & 07336200 & Kiamichi River near Antlers, Okla. & 42 & Altered & 34.25 & -95.61 & $1,158.3$ \\
\hline 19 & 07341200 & Saline River near Lockesburg, Ark. & 42 & Altered & 33.96 & -94.06 & 259.3 \\
\hline 20 & 07152000 & Chikaskia River near Blackwell, Okla. & 42 & Altered & 36.81 & -97.28 & $1,921.6$ \\
\hline 21 & 07243500 & Deep Fork near Beggs, Okla. & 42 & Altered & 35.67 & -96.07 & $2,056.2$ \\
\hline 22 & 07247500 & Fourche Maline near Red Oak, Okla. & 44 & Altered & 34.91 & -95.16 & 123.5 \\
\hline 23 & 07247000 & Poteau River at Cauthron, Ark. & 44 & Altered & 34.92 & -94.30 & 208.8 \\
\hline 24 & 07300500 & Salt Fork Red River at Mangum, Okla. & 44 & Altered & 34.86 & -99.51 & $1,380.4$ \\
\hline 25 & 07177500 & Bird Creek near Sperry, Okla. & 44 & Altered & 36.28 & -95.95 & 930.5 \\
\hline 26 & 07338500 & Little River near Idabel, Okla. & 42 & Altered & 33.94 & -94.76 & 1,260 \\
\hline 27 & 07339000 & Mountain Fork near Eagletown, Okla. & 42 & Altered & 34.04 & -94.62 & 820.5 \\
\hline 28 & 07316500 & Washita River near Cheyenne, Okla. & 44 & Altered & 35.63 & -99.67 & 782.3 \\
\hline
\end{tabular}


Table 3. Distribution of 5 th and 95th percentiles for 27 hydrologic indices for the four hydroecological integrity assessment process groups at 28 streams in Oklahoma.

[Distribution types: N, normal; LN, lognormal; EX, exponential; W2, Weibull 2 parameter; W3, Weibull 3 parameter; JS, Johnson Su. 5Q, 5th percentile; 95Q, 95th percentile; 41-44, group designations from Turton and others (2009). Hydrologic indices are described in table 1]

\begin{tabular}{|c|c|c|c|c|c|c|}
\hline & \multicolumn{3}{|c|}{41} & \multicolumn{3}{|c|}{42} \\
\hline & $5 Q$ & $95 Q$ & Distribution & $5 Q$ & $95 Q$ & Distribution \\
\hline MA01 & 3.55 & 410.01 & W2 & 52.11 & $1,741.29$ & W2 \\
\hline MA04 & 52.19 & 151.38 & $\mathrm{~N}$ & 130.35 & 223.78 & LN \\
\hline MA28 & 51.73 & 145.58 & $\mathrm{~N}$ & 104.49 & 173.71 & W2 \\
\hline ML01 & 2.12 & 112.6 & W2 & 11.16 & 412.55 & LN \\
\hline ML09 & 0.55 & 53.61 & W2 & 0.72 & 34.6 & W2 \\
\hline MH04 & 56.35 & $3,291.1$ & $\mathrm{EX}$ & 657.43 & $16,780.43$ & W2 \\
\hline MH14 & 19.57 & 94.54 & $\mathrm{~N}$ & 49.44 & 271.9 & LN \\
\hline MH20 & 2.66 & 44.01 & W2 & 7.58 & 57.67 & $\mathrm{~N}$ \\
\hline FL03 & 0 & 4.84 & LN & 3.8 & 10.27 & JS \\
\hline FH01 & 4.8 & 14.65 & $\mathrm{~N}$ & 8.09 & 13.61 & W2 \\
\hline FH04 & 2.9 & 31.78 & $\mathrm{~N}$ & 29.79 & 77.25 & $\mathrm{~N}$ \\
\hline FH05 & 4.47 & 14.1 & $\mathrm{~N}$ & 5.74 & 10.84 & $\mathrm{~N}$ \\
\hline DL03 & 0.21 & 40.19 & W2 & 0.18 & 17.18 & W2 \\
\hline DL05 & 1.3 & 101.41 & W2 & 7.16 & 273.01 & LN \\
\hline DL18 & 0 & 25.97 & LN & 0 & 37.11 & W2 \\
\hline DH02 & 61.73 & $7,328.48$ & W2 & 1,129.89 & $28,740.19$ & W2 \\
\hline DH07 & 41.84 & 108.1 & $\mathrm{~N}$ & 45.53 & 88.29 & JS \\
\hline DH10 & 34.17 & 94.76 & LN & 37.31 & 78.07 & LN \\
\hline DH15 & 4.59 & 12.97 & LN & 6.38 & 11.59 & JS \\
\hline DH21 & 31.56 & 118.72 & $\mathrm{~N}$ & 59.12 & 148.17 & JS \\
\hline DH23 & 1.19 & 2.69 & $\mathrm{LN}$ & 1.33 & 6.82 & JS \\
\hline TA01 & 0.22 & 0.57 & $\mathrm{~N}$ & 0.19 & 0.37 & $\mathrm{~N}$ \\
\hline TL01 & 233.62 & 272.37 & $\mathrm{~N}$ & 241.76 & 276.33 & LN \\
\hline TH01 & 36.94 & 220.7 & $\mathrm{~N}$ & 33.14 & 175.88 & $\mathrm{~N}$ \\
\hline RA03 & 1.43 & 172.29 & W2 & 31.05 & 568.34 & W2 \\
\hline RA05 & 0.18 & 0.31 & $\mathrm{~N}$ & 0.17 & 0.28 & $\mathrm{~N}$ \\
\hline RA07 & 0.05 & 0.14 & LN & 0.11 & 0.2 & $\mathrm{~N}$ \\
\hline
\end{tabular}




\begin{tabular}{|c|c|c|c|c|c|c|}
\hline & \multicolumn{3}{|c|}{43} & \multicolumn{3}{|c|}{44} \\
\hline & $5 Q$ & $95 Q$ & Distribution & $5 Q$ & $95 Q$ & Distribution \\
\hline MA01 & 315.56 & $1,898.69$ & $\mathrm{LN}$ & 12.49 & 294.59 & W2 \\
\hline MA04 & 81 & 142.91 & $\mathrm{~N}$ & 131.15 & 280.78 & $\mathrm{~N}$ \\
\hline MA28 & 51.29 & 108.6 & $\mathrm{~N}$ & 153.49 & 266.07 & $\mathrm{~N}$ \\
\hline ML01 & 151.89 & 507.03 & LN & 0.85 & 27.94 & W2 \\
\hline ML09 & 66.34 & 213.08 & LN & 0.03 & 8.08 & W2 \\
\hline MH04 & 939.04 & $18,286.59$ & W2 & 103.99 & $4,592.21$ & W2 \\
\hline MH14 & 16.86 & 56.82 & $\mathrm{~N}$ & 86.83 & $1,087.91$ & W2 \\
\hline MH20 & 12.64 & 29.38 & $\mathrm{LN}$ & 2.89 & 60.49 & W2 \\
\hline FL03 & 0.01 & 2.13 & W2 & 5.46 & 12.14 & W3 \\
\hline FH01 & 5.77 & 10.49 & LN & 9.66 & 15.48 & $\mathrm{~N}$ \\
\hline FH04 & 7.54 & 34.7 & $\mathrm{~N}$ & 20.32 & 105.14 & $\mathrm{~N}$ \\
\hline FH05 & 4.86 & 7.36 & $\mathrm{LN}$ & 6.31 & 15.36 & $\mathrm{LN}$ \\
\hline DL03 & 50.16 & 169.4 & $\mathrm{LN}$ & 0 & 5.14 & W3 \\
\hline DL05 & 82.02 & 351.56 & $\mathrm{~N}$ & 0.98 & 32.98 & W2 \\
\hline DL18 & 0 & 0 & & 6.09 & 140.62 & W2 \\
\hline DH02 & $2,149.5$ & $34,131.3$ & W2 & 447.79 & $7,895.62$ & W2 \\
\hline DH07 & 61.64 & 88.78 & W2 & 46.25 & 138.96 & $\mathrm{LN}$ \\
\hline DH10 & 52.1 & 64.36 & $\mathrm{~N}$ & 52.67 & 112.7 & $\mathrm{LN}$ \\
\hline DH15 & 6.71 & 13.78 & $\mathrm{~N}$ & 3.92 & 8.5 & $\mathrm{~N}$ \\
\hline DH21 & 77.76 & 132.91 & $\mathrm{~N}$ & 38.44 & 122.13 & $\mathrm{~N}$ \\
\hline DH23 & 1.33 & 4.07 & $\mathrm{~N}$ & 1.3 & 3.66 & $\mathrm{LN}$ \\
\hline TA01 & 0.48 & 0.59 & $\mathrm{~N}$ & 0.2 & 0.38 & $\mathrm{LN}$ \\
\hline TL01 & 258.93 & 280.4 & $\mathrm{~N}$ & 236.26 & 271.14 & W3 \\
\hline TH01 & 82.6 & 146.14 & $\mathrm{~N}$ & 88.46 & 207.1 & $\mathrm{~N}$ \\
\hline RA03 & 45.6 & 470.91 & W2 & 28.64 & 206.04 & $\mathrm{LN}$ \\
\hline RA05 & 0.21 & 0.26 & $\mathrm{~N}$ & 0.16 & 0.28 & $\mathrm{LN}$ \\
\hline RA07 & 0.04 & 0.08 & $\mathrm{~N}$ & 0.14 & 0.37 & $\mathrm{LN}$ \\
\hline
\end{tabular}


Table 4. Observed and predicted hydroecological integrity assessment process grouping with discriminant analysis for 28 Oklahoma streamgages.

[Misclassified gages are in bold. HIP, hydroecological integrity assessment process; No., no., number; USGS, U.S. Geological Survey]

\begin{tabular}{|c|c|c|c|c|c|}
\hline $\begin{array}{c}\text { USGS } \\
\text { streamgage } \\
\text { no. }\end{array}$ & Actual HIP & $\begin{array}{l}\text { Predicted } \\
\text { HIP }\end{array}$ & $\begin{array}{c}\text { No. of } \\
\text { indices } \\
\text { exceeded }\end{array}$ & $\begin{array}{c}\text { Mean percent } \\
\text { indices } \\
\text { exceeded }\end{array}$ & Stream type \\
\hline 07196900 & 42 & 42 & 5 & 11.2 & Reference \\
\hline 07197000 & 41 & 41 & 2 & 25.4 & Reference \\
\hline 07151500 & 41 & 41 & 0 & 0.0 & Reference \\
\hline 07189000 & 43 & 43 & 2 & 11.9 & Reference \\
\hline 07195800 & 41 & 41 & 0 & 0.0 & Reference \\
\hline 07337900 & 42 & 42 & 3 & 15.4 & Reference \\
\hline 07249400 & 42 & 42 & 0 & 0.0 & Reference \\
\hline 07335700 & 42 & 42 & 6 & 23.4 & Reference \\
\hline 07249985 & 42 & 42 & 3 & 3.4 & Reference \\
\hline 07184000 & 44 & 44 & 0 & 0.0 & Reference \\
\hline 07315700 & 44 & 44 & 0 & 0.0 & Reference \\
\hline 07187000 & 43 & 43 & 5 & 24.3 & Reference \\
\hline 07191220 & 41 & 41 & 1 & 2.8 & Reference \\
\hline 07186000 & 43 & 43 & 4 & 4.5 & Reference \\
\hline 07170700 & 44 & 44 & 6 & 33.1 & Altered \\
\hline 07332500 & 41 & 41 & 3 & 14.3 & Altered \\
\hline 07172000 & 42 & 42 & 2 & 7.0 & Altered \\
\hline 07336200 & 42 & 42 & 0 & 0.0 & Altered \\
\hline 07341200 & 42 & 42 & 7 & 8.3 & Altered \\
\hline 07152000 & 42 & 43 & 6 & 70.1 & Altered \\
\hline 07243500 & 42 & 43 & 9 & 32.7 & Altered \\
\hline 07247500 & 44 & 42 & 5 & 9.3 & Altered \\
\hline 07247000 & 44 & 42 & 6 & 56.6 & Altered \\
\hline 07300500 & 44 & 42 & 9 & 24.4 & Altered \\
\hline 07177500 & 44 & 43 & 16 & 243.4 & Altered \\
\hline 07338500 & 42 & 43 & 13 & 42.3 & Altered \\
\hline 07339000 & 42 & No class & 17 & 181.3 & Altered \\
\hline 07316500 & 44 & 41 & 12 & 49.8 & Altered \\
\hline
\end{tabular}


Table 5. Correlations between first and second nonmetric multidimensional scaling (NMS) axes of species presence and functional groups with flow variables.

[Correlations in bold typeface have an absolute $r$ value greater than 0.5. Hydrologic indices (variables) are described in table 1. NMS, nonmetric multidimensional scaling]

\begin{tabular}{|c|c|c|c|c|}
\hline \multirow{2}{*}{ Variable } & \multicolumn{2}{|c|}{ Species } & \multicolumn{2}{|c|}{ Functional group } \\
\hline & NMS1 & NMS2 & PC1 & PC2 \\
\hline MA01 & -0.28 & 0.32 & -0.03 & -0.63 \\
\hline MA04 & -0.63 & -0.04 & 0.65 & -0.16 \\
\hline MA28 & -0.53 & 0.03 & 0.57 & -0.16 \\
\hline ML01 & -0.04 & 0.34 & -0.23 & -0.58 \\
\hline ML09 & 0.14 & -0.13 & -0.23 & -0.15 \\
\hline MH04 & -0.34 & 0.33 & 0.04 & -0.67 \\
\hline MH14 & -0.40 & -0.24 & 0.55 & 0.01 \\
\hline MH20 & 0.25 & 0.03 & -0.17 & 0.09 \\
\hline FL03 & -0.56 & -0.06 & 0.63 & 0.01 \\
\hline FH01 & -0.44 & 0.27 & 0.34 & -0.29 \\
\hline FH04 & -0.61 & 0.02 & 0.58 & -0.18 \\
\hline FH05 & -0.46 & 0.03 & 0.45 & -0.06 \\
\hline DL03 & 0.20 & -0.16 & -0.27 & -0.09 \\
\hline DL05 & -0.07 & 0.15 & -0.17 & -0.49 \\
\hline DL18 & -0.41 & -0.40 & 0.59 & 0.27 \\
\hline DH07 & -0.14 & -0.70 & 0.39 & 0.42 \\
\hline DH10 & -0.52 & -0.64 & 0.74 & 0.32 \\
\hline DH15 & 0.48 & -0.14 & -0.41 & 0.17 \\
\hline DH21 & 0.05 & -0.31 & -0.02 & 0.05 \\
\hline DH23 & -0.39 & -0.28 & 0.31 & 0.03 \\
\hline TA01 & -0.52 & -0.05 & 0.59 & 0.01 \\
\hline TL01 & 0.15 & -0.24 & -0.20 & -0.10 \\
\hline TH01 & -0.12 & -0.12 & 0.00 & -0.08 \\
\hline RA03 & -0.52 & -0.54 & 0.63 & 0.08 \\
\hline RA05 & -0.41 & 0.35 & 0.12 & -0.71 \\
\hline RA07 & -0.17 & 0.08 & 0.03 & -0.13 \\
\hline
\end{tabular}


Table 6. Average proportions of species in functional groups for alteration and geographic location of streamgages on the Kiamichi River and Bird Creek, Oklahoma.

[Values in bold typeface are higher and significantly different between reference and altered periods]

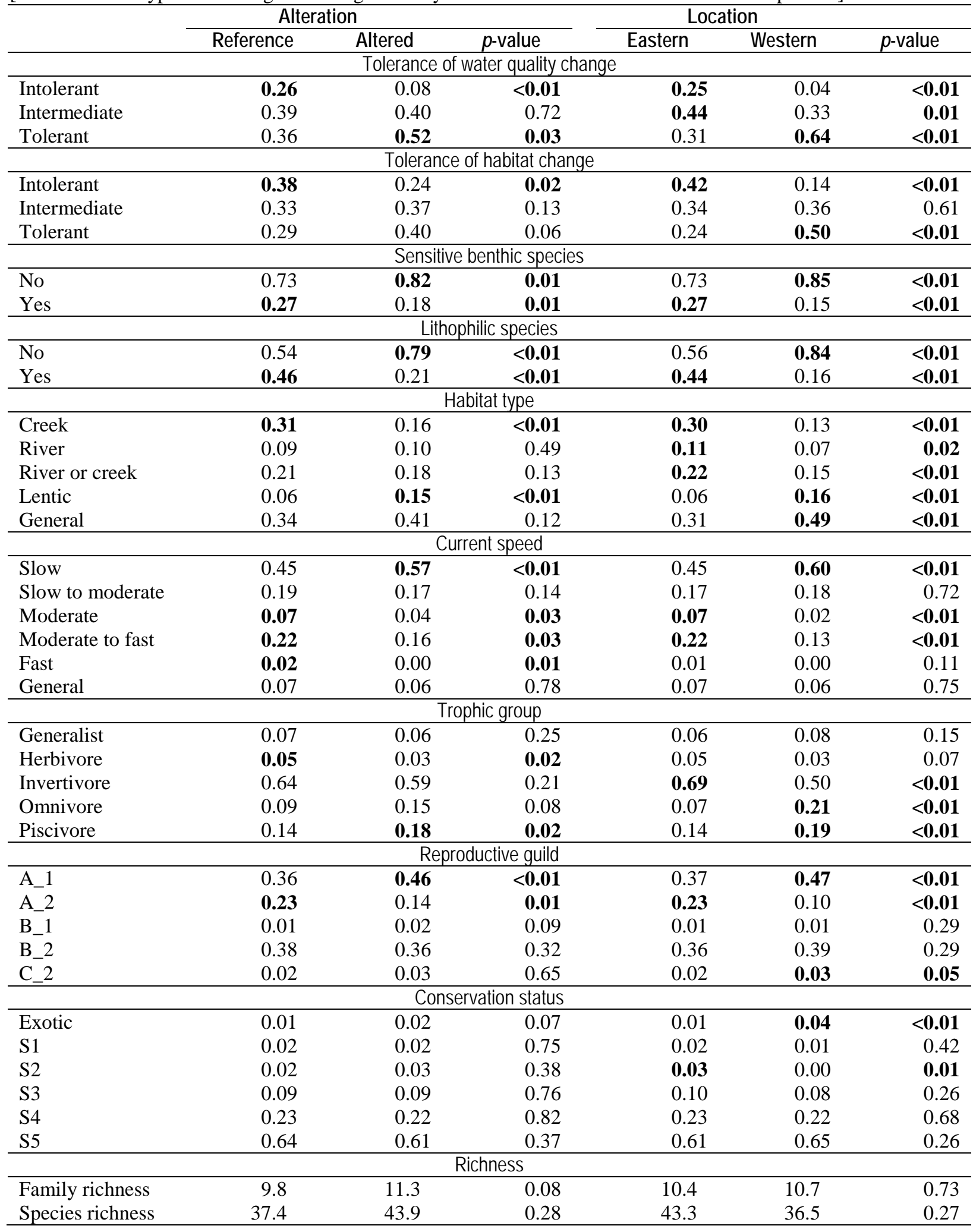


Table 7. Differences between periods in median and coefficient of dispersion values for hydrologic parameters for the Kiamichi River, Oklahoma.

[Results are based on indicators of hydrologic analysis between pre- and post-impoundment periods. Values in bold typeface are significantly different between pre- and post-impoundment periods. CD, coefficient of dispersion; L-RVA, boundary for lower range of natural variability; H-RVA, boundary for upper range of natural variability; $p$ (Med.), proportion of randomized trials where difference between pre and post impoundment median values were greater than observed values; $p(C D)$, proportion of randomized trials where difference between pre and post impoundment CD values were greater than observed values]

\begin{tabular}{|c|c|c|c|c|c|c|c|c|}
\hline & \multicolumn{4}{|c|}{ Pre-impoundment } & \multicolumn{4}{|c|}{ Post Sardis Lake impoundment } \\
\hline & Median & CD & L-RVA & H-RVA & Median & $C D$ & $\mathrm{p}$ (Med.) & $\mathrm{p}(\mathrm{CD})$ \\
\hline \multicolumn{9}{|c|}{ Magnitude of monthly water conditions } \\
\hline October & 90 & 2.9 & 14 & 172 & 31 & 5.4 & 0.38 & 0.22 \\
\hline November & 178.5 & 2.9 & 96 & 482.1 & 339 & 5.4 & 0.19 & 0.11 \\
\hline December & 356 & 1.6 & 246.4 & 676 & 1,100 & 2.0 & $<0.01$ & 0.54 \\
\hline January & 641 & 1.3 & 401.4 & 943 & 553 & 3.5 & 0.62 & $<0.01$ \\
\hline February & 986 & 1 & 555.4 & 1,376 & 872.5 & 1.6 & 0.91 & 0.16 \\
\hline March & 1,100 & 1 & 793 & 1,520 & 1,420 & 1 & 0.26 & 0.79 \\
\hline April & 1,055 & 1.5 & 845.2 & 1,610 & 1,077 & 2.2 & 0.87 & 0.08 \\
\hline May & 916 & 1.3 & 593 & 1,368 & 1,350 & 1.6 & 0.10 & 0.46 \\
\hline June & 272 & 1.8 & 155.7 & 507.1 & 322.5 & 3.1 & 0.32 & 0.09 \\
\hline July & 53 & 2.8 & 26.5 & 127.6 & 46 & 2.1 & 0.71 & 0.59 \\
\hline August & 27 & 2.9 & 6.2 & 57.5 & 12 & 5.1 & 0.24 & 0.16 \\
\hline September & 40 & 2.7 & 14.7 & 84.1 & 35.5 & 2.2 & 0.80 & 0.68 \\
\hline \multicolumn{9}{|c|}{ Magnitude and duration of annual extreme conditions } \\
\hline 1-day minimum flow & 0.6 & 11.7 & 0.1 & 3.9 & 1.5 & 2.8 & 0.13 & 0.22 \\
\hline 3-day minimum flow & 0.6 & 12.5 & 0.1 & 4.2 & 1.9 & 2.4 & 0.10 & 0.23 \\
\hline 7-day minimum flow & 1 & 11.9 & 0.2 & 4.5 & 2.4 & 2.2 & 0.13 & 0.23 \\
\hline 30-day minimum flow & 5.5 & 5 & 2.9 & 18.7 & 6.5 & 1.2 & 0.72 & 0.23 \\
\hline 90-day minimum flow & 91.4 & 2.6 & 46.2 & 150.3 & 77.8 & 1.1 & 0.58 & 0.31 \\
\hline 1-day maximum flow & 31,100 & 0.6 & 24,800 & 38,960 & 23,100 & 0.6 & 0.07 & 0.69 \\
\hline 3-day maximum flow & 26,070 & 0.7 & 21,580 & 34,460 & 18,630 & 0.7 & 0.04 & 0.98 \\
\hline 7-day maximum flow & 14,880 & 0.7 & 13,700 & 21,410 & 11,160 & 0.7 & 0.04 & 0.99 \\
\hline 30-day maximum flow & 6,630 & 0.7 & 4,974 & 8,173 & 5,299 & 0.7 & 0.17 & 0.86 \\
\hline 90-day maximum flow & 3,494 & 0.7 & 3,178 & 4,703 & 3,419 & 0.5 & 0.76 & 0.32 \\
\hline \# of zero-flow days & 0 & 0 & 0 & 0 & 0 & 0 & & \\
\hline \multicolumn{9}{|c|}{ Timing of annual extreme water conditions } \\
\hline Julian date of 1-day max & 253 & 0.1 & 232 & 272.5 & 258 & 0.1 & 0.82 & 0.60 \\
\hline Julian date of 1-day min & 124 & 0.5 & 106.5 & 154.4 & 136 & 0.5 & 0.41 & 0.94 \\
\hline \multicolumn{9}{|c|}{ Frequency and duration of high and low pulses } \\
\hline \# of low pulses per year & 4 & 0.8 & 4 & 5 & 4 & 0.8 & 0.71 & 0.85 \\
\hline Duration of low pulses & 9 & 1.2 & 8 & 15.3 & 10.5 & 1.3 & 0.48 & 0.81 \\
\hline \# of high pulses per year & 12 & 0.4 & 11 & 14.5 & 14 & 0.3 & 0.05 & 0.25 \\
\hline Duration of high pulses & 5 & 0.4 & 4 & 5.5 & 4.5 & 0.7 & 0.29 & 0.05 \\
\hline \multicolumn{9}{|c|}{ Rate and frequency of water condition changes } \\
\hline Rise rates & 235 & 1.4 & 124.2 & 343.8 & 201 & 1.4 & 0.68 & 0.91 \\
\hline Fall rates & -48 & -1.1 & -68.1 & -32.5 & -45 & -1.6 & 0.91 & 0.08 \\
\hline \# of reversals & 73 & 0.2 & 66 & 78 & 80 & 0.2 & 0.04 & 0.99 \\
\hline
\end{tabular}


Table 8. Differences between periods in median and coefficient of dispersion values for hydrologic parameters for Bird Creek, Oklahoma.

[Results are based on indicators of hydrologic analysis between pre- and post-impoundment periods. Values in bold typeface are significantly different between pre and post impoundment periods. CD, coefficient of dispersion; L-RVA, boundary for lower range of natural variability; H-RVA, boundary for upper range of natural variability; $p$ (Med.), proportion of randomized trials where difference between pre and post impoundment median values were greater than observed values; $p(\mathrm{CD})$, proportion of randomized trials where difference between pre and post impoundment $C D$ values were greater than observed values]

\begin{tabular}{|c|c|c|c|c|c|c|c|c|c|c|c|c|}
\hline & \multicolumn{4}{|c|}{ Pre-impoundment } & \multicolumn{4}{|c|}{ Post Birch Lake impoundment } & \multicolumn{4}{|c|}{ Post Skiatook Lake impoundment } \\
\hline & Median & CD & L-RVA & H-RVA & Median & CD & p(Med.) & $p(C D)$ & Median & $C D$ & p(Med.) & $\mathrm{p(CD)}$ \\
\hline \multicolumn{13}{|c|}{ Magnitude of monthly water conditions } \\
\hline October & 12 & 6.8 & 3.6 & 64.2 & 8.7 & 1.3 & 0.81 & 0.34 & 154 & 0.5 & $<0.01$ & 0.18 \\
\hline November & 19 & 3.9 & 6.2 & 45.5 & 18.5 & 5.7 & 0.98 & 0.68 & 79 & 6.2 & $<0.01$ & 0.49 \\
\hline December & 25 & 3.0 & 7.6 & 53 & 25 & 0.6 & 0.98 & 0.52 & 114 & 1.5 & $<0.01$ & 0.23 \\
\hline January & 37 & 2.3 & 15.6 & 76.8 & 19 & 0.9 & 0.48 & 0.37 & 88 & 2.4 & $<0.01$ & 0.92 \\
\hline February & 36 & 2.9 & 15.1 & 90.3 & 87 & 2.1 & 0.17 & 0.77 & 107 & 1.5 & $<0.01$ & 0.28 \\
\hline March & 60 & 3.4 & 36.0 & 147.4 & 93 & 2.5 & 0.52 & 0.78 & 220 & 6.0 & 0.01 & 0.25 \\
\hline April & 137 & 1.9 & 47.6 & 251 & 204 & 1.4 & 0.69 & 0.76 & 249 & 3.8 & 0.01 & 0.20 \\
\hline May & 153 & 1.5 & 98.6 & 244 & 446 & 4.4 & 0.02 & 0.35 & 315 & 5.2 & $<0.01$ & 0.03 \\
\hline June & 91.5 & 1.6 & 39.8 & 153.9 & 181.5 & 1.5 & 0.06 & 0.95 & 273 & 5.6 & $<0.01$ & 0.07 \\
\hline July & 27 & 2.8 & 15.1 & 69 & 27 & 1.9 & 0.92 & 0.70 & 183 & 0.7 & $<0.01$ & 0.19 \\
\hline August & 10 & 2.2 & 5.3 & 19 & 15 & 1.2 & 0.48 & 0.70 & 159 & 0.3 & $<0.01$ & 0.25 \\
\hline September & 10 & 7.0 & 6.5 & 42.2 & 9.4 & 0.9 & 0.88 & 0.35 & 159.5 & 0.1 & $<0.01$ & 0.31 \\
\hline \multicolumn{13}{|c|}{ Magnitude and duration of annual extreme conditions } \\
\hline 1-day minimum flow & 1.2 & 3.4 & 0.2 & 2.1 & 1.8 & 0.6 & 0.58 & 0.46 & 49 & 0.4 & $<0.01$ & 0.21 \\
\hline 3-day minimum flow & 1.2 & 3.5 & 0.3 & 2.2 & 2 & 0.6 & 0.48 & 0.41 & 50.7 & 0.3 & $<0.01$ & 0.19 \\
\hline 7-day minimum flow & 1.6 & 3.0 & 0.5 & 3.8 & 2.3 & 0.8 & 0.60 & 0.38 & 54.1 & 0.3 & $<\mathbf{0 . 0 1}$ & 0.12 \\
\hline 30-day minimum flow & 3.6 & 2.8 & 1.3 & 8.6 & 5.5 & 0.5 & 0.46 & 0.45 & 64.6 & 0.3 & $<0.01$ & 0.09 \\
\hline 90-day minimum flow & 17 & 4.3 & 10.7 & 48.6 & 21.2 & 0.7 & 0.79 & 0.27 & 132.3 & 0.8 & $<0.01$ & 0.13 \\
\hline 1-day maximum flow & 13,800 & 0.7 & 10,760 & 17,330 & 9,410 & 0.6 & 0.20 & 0.95 & 12,900 & 0.7 & 0.77 & 0.70 \\
\hline 3-day maximum flow & 9,853 & 0.8 & 7,404 & 12,440 & 6,540 & 0.6 & 0.27 & 0.84 & 8,130 & 0.9 & 0.62 & 0.56 \\
\hline 7-day maximum flow & 5,645 & 1.0 & 3,754 & 6,864 & 3,942 & 0.9 & 0.31 & 0.88 & 6,613 & 0.7 & 0.43 & 0.40 \\
\hline 30-day maximum flow & 2,169 & 0.8 & 1,479 & 2,607 & 1,954 & 1.2 & 0.77 & 0.65 & 3,115 & 0.8 & 0.04 & 0.95 \\
\hline 90-day maximum flow & 1,136 & 1.0 & 791.2 & 1,340 & 1,215 & 0.8 & 0.79 & 0.82 & 1,429 & 1.4 & 0.10 & 0.25 \\
\hline \# of zero-flow days & 0 & 0 & 0 & 0 & 0 & 0.0 & & & 0 & 0.0 & & \\
\hline$\underline{\text { Base flow index }}$ & 0 & 2.5 & 0 & 0 & 0 & 3.0 & 0.34 & 0.77 & 0.06 & 1.7 & $<0.01$ & 0.59 \\
\hline \multicolumn{13}{|c|}{ Timing of annual extreme water conditions } \\
\hline Julia & 257 & 0.1 & 246.5 & 275 & 283 & 0.1 & 0.11 & 0.63 & 311 & 0.2 & $<0.01$ & 0.40 \\
\hline Julian date of 1-day min & 163 & 0.4 & 133.1 & 226.4 & 139 & 0.2 & 0.63 & 0.12 & 128 & 0.3 & 0.12 & 0.44 \\
\hline
\end{tabular}




\begin{tabular}{|c|c|c|c|c|c|c|c|c|c|c|c|c|}
\hline & \multicolumn{4}{|c|}{ Pre-impoundment } & \multicolumn{4}{|c|}{ Post Birch Lake impoundment } & \multicolumn{4}{|c|}{ Post Skiatook Lake impoundment } \\
\hline & Median & CD & L-RVA & H-RVA & Median & CD & p(Med.) & $p(C D)$ & Median & CD & p(Med.) & $p(C D)$ \\
\hline \multicolumn{13}{|c|}{ Frequency and duration of high and low pulses } \\
\hline \# of low pulses per year & 4 & 1.3 & 2.5 & 5.5 & 4 & 1.5 & 0.73 & 0.67 & 0 & 0 & 0.21 & 0.02 \\
\hline Duration of low pulses & 11.5 & 1 & 9 & 16.8 & 5 & 0.6 & 0.24 & 0.43 & 5.5 & & 0.12 & \\
\hline \# of high pulses per year & 13 & 0.4 & 11 & 14 & 10 & 0.4 & 0.14 & 0.93 & 14 & 0.4 & 0.09 & 0.75 \\
\hline Duration of high pulses & 4 & 0.5 & 3.0 & 5 & 5.5 & 1.0 & 0.09 & 0.24 & 6 & 0.7 & $<\mathbf{0 . 0 1}$ & 0.34 \\
\hline \multicolumn{13}{|c|}{ Rate and frequency of water condition changes } \\
\hline Rise rates & 25 & 2.4 & 11.1 & 46.7 & 8 & 1.3 & 0.30 & 0.70 & 22 & 2.7 & 0.75 & $\overline{0.82}$ \\
\hline Fall rates & -9 & -1.1 & -11 & -5 & -9 & -0.8 & 0.80 & 0.70 & -16.5 & -1.2 & $<0.01$ & 0.83 \\
\hline \# of reversals & 69 & 0.2 & 65 & 76 & 82 & 0.2 & 0.05 & 0.53 & 112 & 0.1 & $<0.01$ & 0.03 \\
\hline
\end{tabular}


Table 9. Correlation coefficients and p-values for best fit environmental vectors describing relationships between environmental flow variables and fish assemblage structure in the Kiamichi River and Bird Creek, Oklahoma.

[Values are based on rotational vector fitting between variables and axes 1 and 2 NMS scores for each site. Bold values represent significant relationships. na, not available]

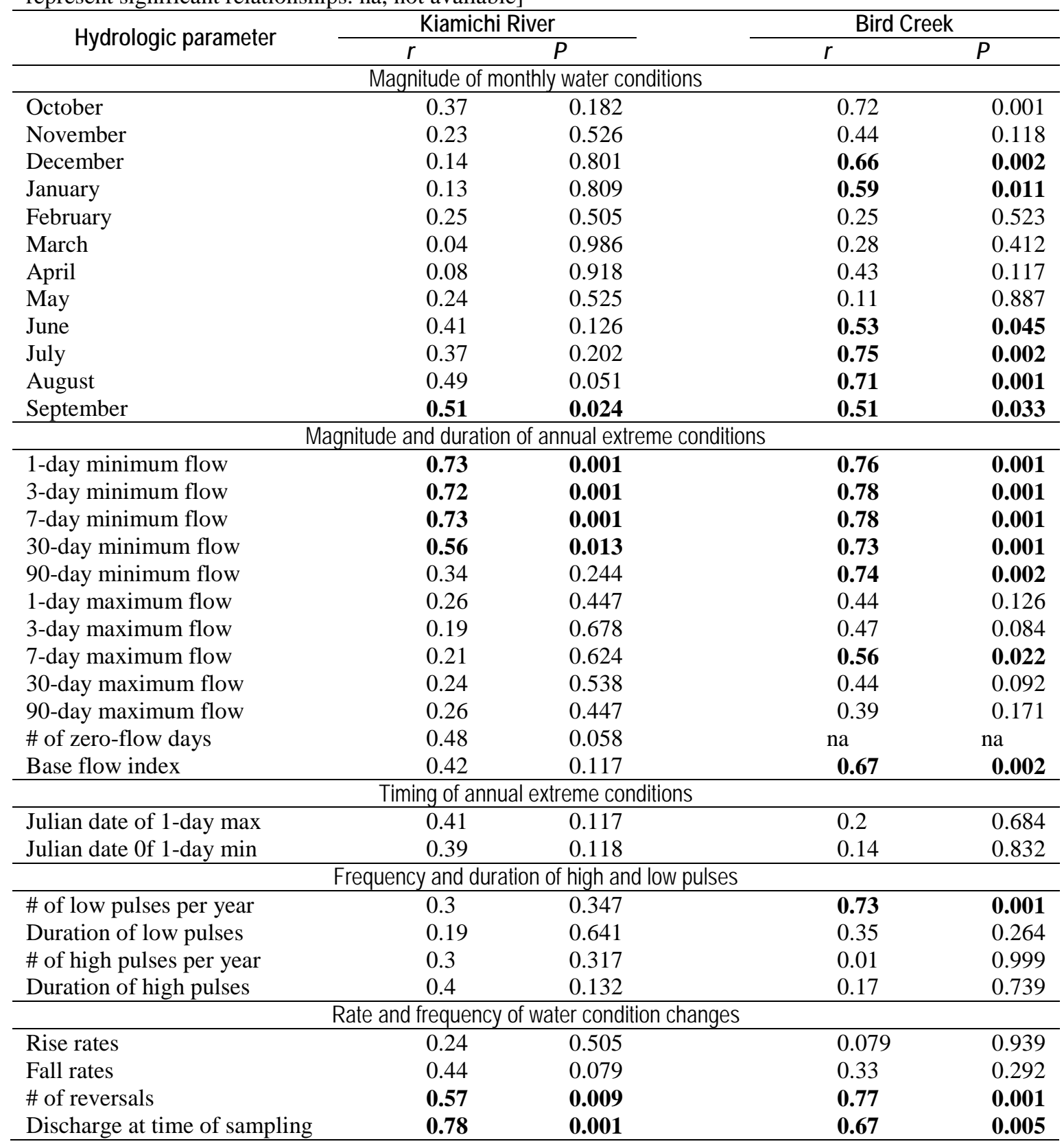


Table 10. Fish species that were significant indicators of pre- or post-impoundment periods on the Kiamichi River and Bird Creek, Oklahoma.

[Periods are divided into pre and post for the categorical variable "Dam.” Additionally, periods were divided into pre (pr), transitional (tran), and post for the categorical variable "Time.” Significance ( $p$ ) is based on a Monte Carlo randomization test where the proportion of randomized trials with indicator value (indval) equal to or exceeding the observed indicator value]

\begin{tabular}{|c|c|c|c|c|c|c|}
\hline \multirow{2}{*}{ Common Name } & \multicolumn{3}{|c|}{ Variable "Dam" } & \multicolumn{3}{|c|}{ Variable "Time" } \\
\hline & Period & Indval & $p$ & Period & Indval & $p$ \\
\hline \multicolumn{7}{|c|}{ Kiamichi River } \\
\hline Blacktail shriner & - & - & - & post & 51.6 & 0.013 \\
\hline Brook silverside & pre & 74.6 & 0.002 & pre & 59.5 & 0.006 \\
\hline Spotted bass & pre & 54.3 & 0.037 & - & - & - \\
\hline Largemouth bass & post & 61.1 & 0.045 & $\operatorname{tran}$ & 49.2 & 0.003 \\
\hline \multicolumn{7}{|c|}{ Bird Creek } \\
\hline Central stoneroller & post & 84.2 & 0.001 & tran & 56.6 & 0.007 \\
\hline Ghost shiner & post & 84 & 0.001 & - & - & - \\
\hline Sand shiner & post & 42.9 & 0.05 & $\operatorname{tran}$ & 46.9 & 0.041 \\
\hline Suckermouth minnow & post & 71.2 & 0.005 & - & - & - \\
\hline Bullhead minnow & post & 67.5 & 0.007 & post & 67.2 & 0.001 \\
\hline Inland silverside & - & - & - & post & 49 & 0.031 \\
\hline Western mosquitofish & post & 62.5 & 0.039 & post & 47 & 0.042 \\
\hline Largemouth bass & post & 56.9 & 0.026 & - & - & - \\
\hline White crappie & - & - & - & post & 57.7 & 0.012 \\
\hline Slenderhead darter & post & 50 & 0.024 & - & - & - \\
\hline
\end{tabular}




\section{Appendix 1.-Family, Scientific Name, Common Name, and Functional Group Membership for Species Observed in This Study}

\begin{tabular}{|c|c|c|}
\hline Family & Scientific name & Common name \\
\hline Aphredoderidae & Aphredoderus sayanus & Pirate perch \\
\hline Aphredoderidae & Labidesthes sicculus & Brook silverside \\
\hline Aphredoderidae & Menidia beryllina & Inland silverside \\
\hline Catostomidae & Carpiodes carpio & River carpsucker \\
\hline Catostomidae & Carpiodes cyprinus & Quillback \\
\hline Catostomidae & Catostomus commersonii & White sucker \\
\hline Catostomidae & Cycleptus elongatus & Blue sucker \\
\hline Catostomidae & Erimyzon sucetta & Lake chubsucker \\
\hline Catostomidae & Hypentelium nigricans & Northern hog sucker \\
\hline Catostomidae & Ictiobus bubalus & Smallmouth buffalo \\
\hline Catostomidae & Ictiobus cyprinellus & Largemouth buffalo \\
\hline Catostomidae & Ictiobus niger & Black buffalo \\
\hline Catostomidae & Minytrema melanops & Spotted sucker \\
\hline Catostomidae & Moxostoma carinatum & River redhorse \\
\hline Catostomidae & Moxostoma duquesnei & Black redhorse \\
\hline Catostomidae & Moxostoma erythrurum & Golden redhorse \\
\hline Catostomidae & Moxostoma macrolepidotum & Shorthead redhorse \\
\hline Centrarchidae & Ambloplites ariommus & Shadow bass \\
\hline Centrarchidae & Ambloplites rupestris & Rock bass \\
\hline Centrarchidae & Centrarchus macropterus & Flier \\
\hline Centrarchidae & Lepomis cyanellus & Green sunfish \\
\hline Centrarchidae & Lepomis gulosus & Warmouth sunfish \\
\hline Centrarchidae & Lepomis humilis & Orangespotted sunfish \\
\hline Centrarchidae & Lepomis macrochirus & Bluegill sunfish \\
\hline Centrarchidae & Lepomis marginatus & Dollar sunfish \\
\hline Centrarchidae & Lepomis megalotis & Longear sunfish \\
\hline Centrarchidae & Lepomis microlophus & Redear sunfish \\
\hline Centrarchidae & Lepomis miniatus & Redspotted sunfish \\
\hline Centrarchidae & Lepomis symmetricus & Bantam sunfish \\
\hline Centrarchidae & Micropterus dolomieu & Smallmouth bass \\
\hline Centrarchidae & Micropterus punctulatus & Spotted bass \\
\hline Centrarchidae & Micropterus salmoides & Largemouth bass \\
\hline Centrarchidae & Pomoxis annularis & White crappie \\
\hline Centrarchidae & Pomoxis nigromaculatus & Black crappie \\
\hline Clupeidae & Dorosoma cepedianum & Gizzard shad \\
\hline Clupeidae & Dorosoma petenense & Threadfin shad \\
\hline Cottidae & Cottus carolinae & Banded sculpin \\
\hline Cyprinidae & Campostoma anomalum & Central stoneroller \\
\hline
\end{tabular}




\begin{tabular}{|c|c|c|}
\hline Family & Scientific name & Common name \\
\hline Cyprinidae & Campostoma oligolepis & Largescale stoneroller \\
\hline Cyprinidae & Carassius auratus & Goldfish \\
\hline Cyprinidae & Cyprinella camura & Bluntface shiner \\
\hline Cyprinidae & Cyprinella lutrensis & Red shiner \\
\hline Cyprinidae & Cyprinella spiloptera & Spotfin shiner \\
\hline Cyprinidae & Cyprinella venusta & Blacktail shiner \\
\hline Cyprinidae & Cyprinella whipplei & Steelcolor shiner \\
\hline Cyprinidae & Cyprinus carpio & Common carp \\
\hline Cyprinidae & Erimystax x-punctatus & Gravel chub \\
\hline Cyprinidae & Hybognathus placitus & Plains minnow \\
\hline Cyprinidae & Hybopsis amblops & Bigeye chub \\
\hline Cyprinidae & Hybopsis amnis & Pallid shiner \\
\hline Cyprinidae & Luxilus cardinalis & Cardinal shiner \\
\hline Cyprinidae & Luxilus chrysocephalus & Striped shiner \\
\hline Cyprinidae & Luxilus pilsbryi & Duskystripe shiner \\
\hline Cyprinidae & Lythrurus fumeus & Ribbon shiner \\
\hline Cyprinidae & Lythrurus snelsoni & Ouachita Mountain shiner \\
\hline Cyprinidae & Lythrurus umbratilis & Redfin shiner \\
\hline Cyprinidae & Macrhybopsis australis & Prairie chub \\
\hline Cyprinidae & Macrhybopsis storeriana & Silver chub \\
\hline Cyprinidae & Nocomis asper & Redspot chub \\
\hline Cyprinidae & Notemigonus crysoleucas & Golden shiner \\
\hline Cyprinidae & Notropis atherinoides & Emerald shiner \\
\hline Cyprinidae & Notropis atrocaudalis & Blackspot shiner \\
\hline Cyprinidae & Notropis bairdi & Red River shiner \\
\hline Cyprinidae & Notropis blennius & River shiner \\
\hline Cyprinidae & Notropis boops & Bigeye shiner \\
\hline Cyprinidae & Notropis buchanani & Ghost shiner \\
\hline Cyprinidae & Notropis greenei & Wedgespot shiner \\
\hline Cyprinidae & Notropis nubilus & Ozark minnow \\
\hline Cyprinidae & Notropis ortenburgeri & Kiamichi shiner \\
\hline Cyprinidae & Notropis percobromus & Carmine shiner \\
\hline Cyprinidae & Notropis perpallidus & Peppered shiner \\
\hline Cyprinidae & Notropis potteri & Chub shiner \\
\hline Cyprinidae & Notropis shumardi & Silverband shiner \\
\hline Cyprinidae & Notropis stramineus & Sand shiner \\
\hline Cyprinidae & Notropis suttkusi & Rocky shiner \\
\hline Cyprinidae & Notropis volucellus & Mimic shiner \\
\hline Cyprinidae & Opsopoeodus emiliae & Pugnose shiner \\
\hline Cyprinidae & Phenacobius mirabilis & Suckermouth minnow \\
\hline Cyprinidae & Phoxinus erythrogaster & Southern redbelly dace \\
\hline Cyprinidae & Pimephales notatus & Bluntnose minnow \\
\hline
\end{tabular}




\begin{tabular}{|c|c|c|}
\hline Family & Scientific name & Common name \\
\hline Cyprinidae & Pimephales promelas & Fathead minnow \\
\hline Cyprinidae & Pimephales tenellus & Slim minnow \\
\hline Cyprinidae & Pimephales vigilax & Bullhead minnow \\
\hline Cyprinidae & Semotilus atromaculatus & Creek chub \\
\hline Cyprinodontidae & Cyprinodon rubrofluviatilis & Red River pupfish \\
\hline Elassomatidae & Elassoma zonatum & Banded pygmy sunfish \\
\hline Esocidae & Esox americanus & Grass pickerel \\
\hline Esocidae & Esox niger & Chain pickerel \\
\hline Fundulidae & Fundulus blaire & Western starhead topminnow \\
\hline Fundulidae & Fundulus catenatus & Northern studfish \\
\hline Fundulidae & Fundulus chrysotus & Golden topminnow \\
\hline Fundulidae & Fundulus kansae & Northern plains killifish \\
\hline Fundulidae & Fundulus notatus & Blackstripe topminnow \\
\hline Fundulidae & Fundulus olivaceus & Blackspotted topminnow \\
\hline Fundulidae & Fundulus sciadicus & Plains topminnow \\
\hline Fundulidae & Fundulus zebrinus & Plains killifish \\
\hline Hiodontidae & Hiodon alosoides & Goldeye \\
\hline Ictaluridae & Ameiurus melas & Black bullhead \\
\hline Ictaluridae & Ameiurus natalis & Yellow bullhead \\
\hline Ictaluridae & Ictalurus furcatus & Blue catfish \\
\hline Ictaluridae & Ictalurus punctatus & Channel catfish \\
\hline Ictaluridae & Noturus eleutherus & Mountain madtom \\
\hline Ictaluridae & Noturus exilis & Slender madtom \\
\hline Ictaluridae & Noturus flavus & Stonecat \\
\hline Ictaluridae & Noturus gyrinus & Tadpole madtom \\
\hline Ictaluridae & Noturus miurus & Brindled madtom \\
\hline Ictaluridae & Noturus nocturnus & Freckeled madtom \\
\hline Ictaluridae & Noturus placidus & Neosho madtom \\
\hline Ictaluridae & Pylodictis olivaris & Flathead catfish \\
\hline Lepisosteidae & Lepisosteus oculatus & Spotted gar \\
\hline Lepisosteidae & Lepisosteus osseus & Longnose gar \\
\hline Lepisosteidae & Lepisosteus platostomus & Shortnose gar \\
\hline Moronidae & Morone chrysops & White bass \\
\hline Moronidae & Morone chrysops $x$ Morone saxatilis & Wiper \\
\hline Moronidae & Morone mississippiensis & Yellow bass \\
\hline Moronidae & Morone saxatilis & Striped bass \\
\hline Percidae & Ammocrypta clara & Western sand darter \\
\hline Percidae & Ammocrypta vivax & Scaly sand darter \\
\hline Percidae & Crystallaria asprella & Crystal darter \\
\hline Percidae & Etheostoma asprigene & Mud darter \\
\hline Percidae & Etheostoma blennioides & Greenside darter \\
\hline Percidae & Etheostoma chlorosoma & Bluntnose darter \\
\hline
\end{tabular}




\begin{tabular}{|c|c|c|}
\hline Family & Scientific name & Common name \\
\hline Percidae & Etheostoma cragini & Arkansas darter \\
\hline Percidae & Etheostoma flabellare & Fantail darter \\
\hline Percidae & Etheostoma gracile & Slough darter \\
\hline Percidae & Etheostoma histrio & Harlequin darter \\
\hline Percidae & Etheostoma microperca & Least darter \\
\hline Percidae & Etheostoma nigrum & Johnny darter \\
\hline Percidae & Etheostoma proeliare & Cypress darter \\
\hline Percidae & Etheostoma punctulatum & Stippled darter \\
\hline Percidae & Etheostoma radiosum & Orangebelly darter \\
\hline Percidae & Etheostoma spectabile & Orangethroat darter \\
\hline Percidae & Etheostoma stigmaeum & Speckled darter \\
\hline Percidae & Etheostoma whipplei & Redfin darter \\
\hline Percidae & Etheostoma zonale & Banded darter \\
\hline Percidae & Percina caprodes & Logperch \\
\hline Percidae & Percina copelandi & Channel darter \\
\hline Percidae & Percina fulvitaenia & Ozark logperch \\
\hline Percidae & Percina macrolepida & Bigscale logperch \\
\hline Percidae & Percina maculata & Blackside darter \\
\hline Percidae & Percina nasuta & Longnose darter \\
\hline Percidae & Percina pantherina & Leopard darter \\
\hline Percidae & Percina phoxocephala & Slenderhead darter \\
\hline Percidae & Percina sciera & Dusky darter \\
\hline Percidae & Percina shumardi & River darter \\
\hline Percidae & Sander canadensis & Sauger \\
\hline Petromyzontidae & Ichthyomyzon castaneus & Chestnut lamprey \\
\hline Petromyzontidae & Ichthyomyzon gagei & Southern brook lamprey \\
\hline Poeciliidae & Gambusia affinis & Mosquitofish \\
\hline Sciaenidae & Aplodinotus grunniens & Freshwater drum \\
\hline
\end{tabular}

